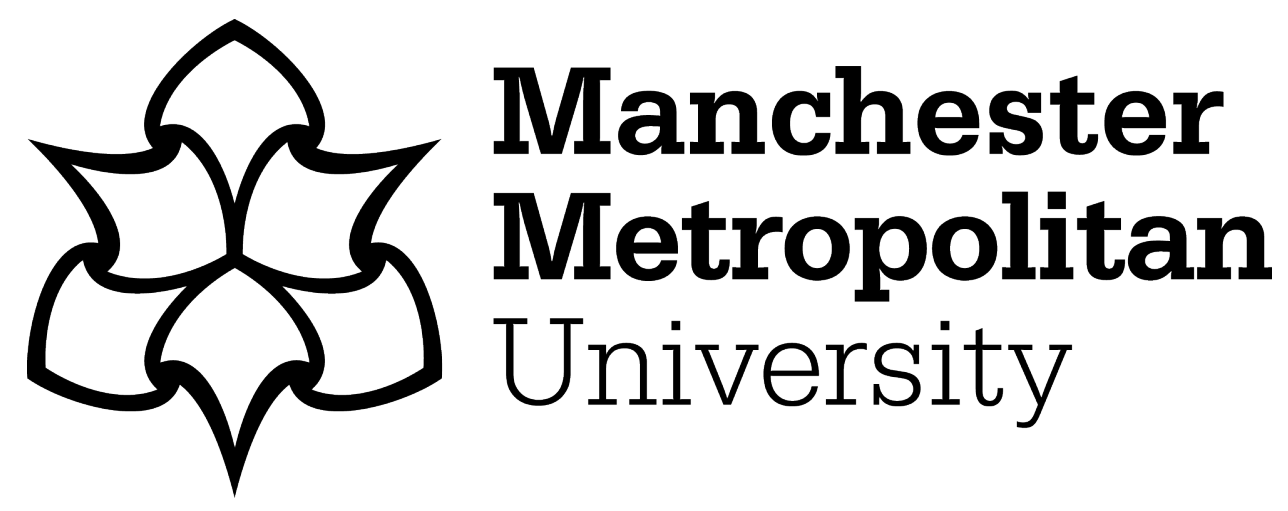

Martínez-Periñán, E, Bravo, I, Rowley-Neale, SJ, Lorenzo, E and Banks, CE (2018) Carbon Nanodots as Electrocatalysts towards the Oxygen Reduction Reaction. Electroanalysis, 30 (3). pp. 436-444. ISSN 1040-0397

Downloaded from: https://e-space.mmu.ac.uk/620585/

Publisher: Wiley

DOI: https://doi.org/10.1002/elan.201700718

Please cite the published version 


\title{
Carbon Nanodots as Electrocatalysts towards the Oxygen Reduction Reaction
}

\author{
Emiliano Martínez-Periñán,, ${ }^{1,2}$ Iria Bravo, ${ }^{1,3}$ Samuel J. Rowley-Neale,,4 Encarnación \\ Lorenzo, ${ }^{1,3}$ and Craig E. Banks ${ }^{2,4 *}$ \\ ${ }^{1}$ : Departamento de Química Analítica y Análisis Instrumental, Universidad Autónoma \\ de Madrid, 28049, Madrid, Spain. \\ 2: Faculty of Science and Engineering, Manchester Metropolitan University, Chester \\ Street, Manchester M1 5GD, UK. \\ 3: IMDEA-Nanoscience, Faraday 9, Campus Cantoblanco-UAM, 28049 Madrid, Spain. \\ 4: Fuel Cell Innovation Center, Manchester Metropolitan University, Chester Street, \\ Manchester M1 5GD, UK. \\ *To whom correspondence should be addressed. \\ Email: c.banks@mmu.ac.uk; Tel: ++(0)1612471196; Fax: ++(0)1612476831 \\ Website: www.craigbanksresearch.com
}




\begin{abstract}
Electrocatalysts perform a key role in increasing efficiency of the oxygen reduction reaction (ORR) and as a result, efforts have been made by the scientific community to develop novel and cheap materials that have the capability to low overpotentials and allow the reaction to occur via a 4 electron pathway, thereby mimicking as close as possible to traditionally utilised platinum. In that context, two different types of carbon nanodots (CNDs) with amide $\left(\mathrm{CND}-\mathrm{CONH}_{2}\right)$ and carboxylic (CND-COOH) surface groups, have herein been fabricated and shown to exhibit excellent electrocatalytic activity towards the ORR in acid and basic media $\left(0.1 \mathrm{M} \mathrm{H}_{2} \mathrm{SO}_{4}\right.$ and $\left.0.1 \mathrm{M} \mathrm{KOH}\right)$. CND surface modified carbon screen-printed electrodes allow for a facile electrode modification and enabling the study of the CNDs electrocatalytic activity towards the ORR. CND-COOH modified SPEs are found to exhibit improved ORR peak current and reduced overpotential by $21.9 \%$ and $26.3 \%$, respectively compared to bare/unmodified SPEs. Additionally, $424 \mu \mathrm{g}$ $\mathrm{cm}^{-2} \mathrm{CND}-\mathrm{COOH}$ modified SPEs in oxygenated $0.1 \mathrm{M} \mathrm{KOH}$ are found to facilitate the ORR via a near optimal 4 (3.8) electron ORR pathway. The CNDs also exhibited excellent long-term stability and tolerance with no degradation being observed in the achievable current with the ORR current returning to the baseline level within 100 seconds of exposure to a $1.5 \mathrm{M}$ solution of methanol. In summary, the CND-COOH could be utilised as a cathodic electrode for PEMFCs offering greater stability than a commercial Pt electrode.
\end{abstract}

Keywords: Carbon nanodots, Oxygen Reduction Reaction, screen-printed electrodes 


\section{Introduction}

In order to address the negative consequences of anthropogenic air pollution and climate change, an impetus has developed to implement clean energy generation techniques. One such approach is the use of proton exchange membrane fuel cells (PEMFC) which utilise the oxidation of hydrogen (known as the hydrogen oxidation reaction (HOR) at the anode) and the reduction of oxygen (known as the oxygen reduction reaction (ORR) at the cathode) in order to generate an electrical current. The ORR has largest influence upon a PEMFCs efficiency, ${ }^{1-3}$ due to the ORR having a large kinetic barrier. ${ }^{4,5}$ The ORR mechanism differs in acidic and basic media; in acid, the pathway occurs via an unfavourable 2 electron pathway, which results in the production of $\mathrm{H}_{2} \mathrm{O}_{2}$, or a 4 electron pathway, where the major product is $\mathrm{H}_{2} \mathrm{O}$ (see below). The 2 electron pathway is undesirable as the product can lead to electrode poisoning and membrane degradation that can significantly reduce a PEMFCs output. ${ }^{6,7}$

Acidic media:

$$
\begin{array}{ll}
\mathrm{O}_{2}+4 \mathrm{H}^{+}+4 \mathrm{e}^{-} \leftrightarrow 2 \mathrm{H}_{2} \mathrm{O} & \text { Direct } \\
\mathrm{O}_{2}+2 \mathrm{H}^{+}+2 \mathrm{e}^{-} \leftrightarrow \mathrm{H}_{2} \mathrm{O}_{2} & \text { Indirect } \\
\mathrm{H}_{2} \mathrm{O}_{2}+2 \mathrm{H}^{+}+2 \mathrm{e}^{-} \leftrightarrow 2 \mathrm{H}_{2} \mathrm{O} &
\end{array}
$$

\section{Alkaline media:}

$$
\begin{array}{ll}
\mathrm{O}_{2}+2 \mathrm{H}_{2} \mathrm{O}+4 \mathrm{e}^{-} \leftrightarrow 4 \mathrm{OH}^{-} & \text {Direct } \\
\mathrm{O}_{2}+\mathrm{H}_{2} \mathrm{O}+2 \mathrm{e}^{-} \leftrightarrow \mathrm{HO}_{2}^{-}+\mathrm{OH}^{-} & \text {Indirect } \\
\mathrm{HO}_{2}^{-}+\mathrm{H}_{2} \mathrm{O}+2 \mathrm{e}^{-} \leftrightarrow 3 \mathrm{OH}^{-} &
\end{array}
$$

In order to increase the performance of PEMFCs, research has concentrated on developing effective, low cost and sustainable new electrocatalysts that can increase the achievable ORR peak current as well as reduce the electrochemical overpotential (less energy is required) and allow the reaction mechanism to occur via a 4 electron pathway. Platinum (Pt), and compounds containing it, are considered the most effective catalysts for the ORR allowing the reaction mechanism to occur via a 4 electron pathway. ${ }^{8,9}$ This is a consequence of its low (near negligible) binding energy of adsorbates like $\mathrm{O}_{2}$ and $\mathrm{H}^{+}$. However, the high cost and poor global distribution of platinum limit the attractiveness 
of its application. ${ }^{10}$ Over the past few decades attempts have been made to develop nonprecious metal catalysts as cost effective alternatives to $\mathrm{Pt}$.

There has been a plethora of potential electrocatalysts developed to meet the criteria described above. Such as non-precious metal oxides, ${ }^{11,} 12$ nitrides, ${ }^{3,}$ 12, 13 carbides, ${ }^{14,} 15$ transition-metal-coordinating macrocyclic compounds, ${ }^{4}$ new $2 \mathrm{~d}$ nanomaterials, ${ }^{5,16,17}$ and metal free heteroatoms doped carbon. ${ }^{18-21}$ Recent studies have focused on doping heteroatoms (e.g., B, N, O, P, S) into carbon based materials in order to increase the electron density near the fermi level, which induces an increase in the electropositive charge on the adjacent carbon atom, resulting in improved oxygen adsorption at the catalyst surface. ${ }^{22-24}$ This approach increases the materials electrocatalytic activity towards the ORR (reducing the ORR overpotential and increasing the achievable current density). ${ }^{25-28}$ The approach of doping has been utilised on a plethora of carbon based materials, as summarised within Table 1. Carbon based quantum dots are of particular interest in this field, since they have inherent benefits compared to other carbon based materials ${ }^{29,30}$ such as their edge-abundant morphology that conveys significant electrocatalytic activity ${ }^{31}$ with their synthesis being facile and comparatively cheap based on a hydrothermal reaction. ${ }^{29,30,32,33}$

In the majority of studies, CNDs have been employed as electrocatalyst along with other support molecules/elements that have acted to keep the nanodots immobilised onto electrode surfaces (see table I). ${ }^{27,32,34,35}$ Herein we describe the beneficial signal output, in regards to the ORR catalytic activity (in acidic and basic media) of CNDs synthesised using a facile technique. $\mathrm{CND}-\mathrm{CONH}_{2}$ are fabricated with ethylene glycol and bis-(2aminoethyl ether)-N,N,N',N'-tetraacetic acid (EGTA) as precursors ${ }^{36}$ while CND$\mathrm{COOH}$ are synthesised using glucose as a precursor. ${ }^{37}$ Both novel CNDs variants are produced using a facile fabrication technique, which mitigates the need for expensive precursors in order to dope CNDs with heteroatoms. No other materials, apart from CNDs, have been used to modify the SPEs utilised herein, with physical adsorption of the CNDs on the electrodes surface as a result of the relative roughness of the SPEs surface. Thus, this work presents a novel approach at producing cost effective alternatives to $\mathrm{Pt}$ as electrode materials for the ORR. 


\section{Experimental}

\subsection{Chemicals}

All the chemicals used within this study were of an analytical grade and were utilised as received from Sigma-Aldrich without any further purification. All solutions were prepared with deionised water of resistivity not less than $18.2 \mathrm{M} \Omega \mathrm{cm}$.

\subsection{CND-CONH2 and CND-COOH Fabrication}

The CNDs have been synthesised according to the techniques reported by Peng et al. ${ }^{37}$ and Ahmed et al. ${ }^{36}$ for the CND-COOH and $\mathrm{CND}-\mathrm{CONH}_{2}$, respectively. In the case of CND-COOH, $2.0 \mathrm{~g}$ of glucose was dissolved in $5 \mathrm{~mL}$ of Milli $\mathrm{Q}$ water. $8 \mathrm{~mL}$ of concentrated $\mathrm{H}_{2} \mathrm{SO}_{4}$ was added under vigorous stirring allowing the reaction to occur for 40 minutes. Following that, $40 \mathrm{~mL}$ of water were added where a black carbonaceous powder was produced. The product is separated via centrifugation (5000 rpm 10 minutes), disposing of the supernatant solution and washing with Milli Q water, repeating the process 4 times. The resulting carbon powder was dispersed in $50 \mathrm{~mL}$ of $\mathrm{HNO}_{3}$ solution $(2.0 \mathrm{M})$ and sonicated for 30 minutes. The generated suspension was refluxed for $12 \mathrm{hrs}$. After that, the mixture was distilled until the final volume of the suspension was $20 \mathrm{~mL}$. After cooling to room temperature, the solution was neutralised by adding $20 \% \mathrm{Na}_{2} \mathrm{CO}_{3}$ solution. The carboxylic carbon nanodots (CND-COOH) obtained were dialysed for three days using $3.5 \mathrm{kD}$ dialysis membrane (Sigma PUR-A-LYZERTM MEGA 3500)). In the case of the CND-CONH 2 preparation: $0.8 \mathrm{~g}$ of EGTA were dissolved in $30 \mathrm{~mL}$ of distilled water generating an acidic white suspension solution. Following that, $1.0 \mathrm{~g}$ of solid Tris was added to the previous solution, producing a clear and $\mathrm{pH}$ neutral solution. The solution was heated at $150{ }^{\circ} \mathrm{C}$ until near dryness at which a pale yellow gel was formed. Then, $1 \mathrm{~mL}$ of water was added and the previous procedure was repeated 5 times in about 30 minutes. The temperature was then increased to $180{ }^{\circ} \mathrm{C}$. The heating continued until the pale yellow gel turned to reddish-orange, indicating the formation of the C-dots. The gel was then dissolved in $25 \mathrm{~mL}$ distilled water, filtered through $0.45 \mu \mathrm{m}$ nylon filter and the solution was purified by dialysis through dialyzer tube (MWCO, 3.5 KDa) for one day. The carbon nanodot final solutions were stored under $4{ }^{\circ} \mathrm{C}$ until use. The CNDs underwent a complete physicochemical characterization, which is described within the Results and Discussion Section. For specific details on the equipment utilised for the characterisation of the CNDs variants, readers are directed towards the ESI. 


\subsection{Electrochemical Measurements}

Voltammetric measurements were performed using an Autolab PGSTAT TYPE III (Metrohm Autolab, The Netherlands) potentiostat using the software package NOVA 1.11. Electrochemical impedance spectroscopy was performed using an Ivium Compactstat $^{\mathrm{TM}}$ (Netherlands) potentiostat. All measurements were conducted, using a conventional three-electrode system utilizing a Saturated Calomel electrode (SCE) and a platinum wire as a reference and counter electrode, respectively. The working electrode was a screen-printed graphite electrode (SPE) (modified with the appropriate amount of CNDs). The SPEs have a $3 \mathrm{~mm}$ diameter working electrode and they were fabricated inhouse with the appropriate stencils using a DEK 248 screen-printing machine (DEK, Weymouth, U.K.). ${ }^{38}$ These fabrication technique, by which, these SPEs are produced, has been meticulously detailed in previous studies. ${ }^{39-44}$

CNDs modified electrodes were prepared by drop-casting aliquots of the desired CNDs solution onto the required working electrode with a micropipette. After 30 minutes, the solvent completely evaporated (at ambient temperature) and the modified electrodes were then ready for use. For ORR measurements, $0.1 \mathrm{M} \mathrm{H}_{2} \mathrm{SO}_{4}$ and $0.1 \mathrm{M} \mathrm{KOH}$ solutions saturated with $\mathrm{O}_{2}$ were used. The solutions were subject to rigorous bubbling of $100 \%$ medicinal grade oxygen through $50 \mathrm{~mL}$ of the solution for 60 minutes (resulting in a 0.9 $\mathrm{mM}$ concentration of oxygen), assuming this to be a completely saturated solution at room temperature as described by Gara. ${ }^{45}$ Where the ORR onset potentials are denoted within the manuscript, note that this is defined as the potential at which the current initially deviates from the background current by a value of $25 \mu \mathrm{A} \mathrm{cm}{ }^{-2}$, thus signifying the commencement of the Faradaic current associated with the ORR redox reaction. 


\section{Results and discussion}

\subsection{Physicochemical characterization of the CND-CONH2 and CND-COOH}

Independent physicochemical characterisation was performed on the synthesised CND$\mathrm{CONH}_{2}$ and CND-COOH using Fourier transform infrared spectroscopy (FT-IR), dynamic light scattering (DLS) and X-ray photoelectron spectroscopy (XPS). Confocal Raman Spectroscopy, using a laser of $532 \mathrm{~nm}$, was performed on the samples, however it was not possible to obtain some adequate spectra as a consequence of the intrinsic fluorescence properties of both CNDs types (data not shown). The size distribution of $\mathrm{CND}-\mathrm{CONH}_{2}$ obtained by measuring the average size of around $100 \mathrm{CDs}$ by DLS (see Figure S1) indicates that these nanoparticles have an average size of $3.4 \mathrm{~nm}$ ranging from 2 to $5 \mathrm{~nm}$ in diameter. In the case of CND-COOH, they have an average size of $2.2 \mathrm{~nm}$ ranging from 1.9 to $3.2 \mathrm{~nm}$. This size is supported using TEM analysis (See Figure S2) where a visual assessment indicates the CNDs are between 1-4 nm in diameter. Note, it is difficult to obtain clear TEM images of the individual CNDs due to their small size. The FT-IR spectra presented in Figure S3 confirms the presence of carboxyl and amide groups on the surface of the $\mathrm{CND}-\mathrm{COOH}^{37}$, and $\mathrm{CND}-\mathrm{CONH} 2,{ }^{36}$ respectively. More details regarding the FT-IR spectrum are described in the ESI. The results of XPS analysis are presented in Table S1 and Figure S4. The atomic concentrations for the CND$\mathrm{COOH}$ and $\mathrm{CND}-\mathrm{CONH}_{2}$ presented in Table $\mathrm{S} 1$ show that there is a higher concentration of oxygen atom for the CND-COOH compared to the $\mathrm{CND}-\mathrm{CONH}_{2}$. This is to be expected as a consequence of the carboxylic (also hydroxyl) groups generated over the carbon nanodots surface as a consequence of it treatment in nitric acid. In the case of $\mathrm{CND}-\mathrm{CONH}_{2}$ a high atomic concentration of nitrogen is observed, this suggest the presence of amide/amine groups on CNDs surface. More details about the XPS analysis are discussed in the ESI. The results of the physicochemical characterisation presented above confirms the presence of carboxylic $(\mathrm{COOH})$ and amide $\left(\mathrm{CONH}_{2}\right)$ functional groups upon the surface of the separately modified CNDs. Last the CND modified SPEs were characterised utilising SEM. Images of their respective surfaces are viewable in Figure S5, however it proved difficult to distinguish between the CNDs and the binder utilised in the SPE production due to the small size of the CNDs which results in a visual distinction between the CNDs modified and bare/unmodified SPEs being unfeasible. 


\subsection{Electrochemical Activity of the CND-COOH and CND-CONH2 towards the ORR}

The $\mathrm{CND}-\mathrm{COOH}$ and $\mathrm{CND}-\mathrm{CONH}_{2}$ were fabricated via the methodology described within the Experimental Section, and CNDs are fully characterised in the section above. The ORR electrocatalytic activity of the $\mathrm{CND}-\mathrm{COOH}$ and $\mathrm{CND}-\mathrm{CONH}_{2}$ was subsequently evaluated.

Figure 1 shows typical linear sweep voltammetry (LSV) obtained for a bare/unmodified SPE, a polycrystalline platinum disc electrode $(\mathrm{Pt})$ and SPEs separately modified with 21 , 42, 106, 212 and $424 \mu \mathrm{g} \mathrm{cm}^{-2}$ of CND-COOH and CND-CONH 2 in oxygenated solutions of $0.1 \mathrm{M} \mathrm{H}_{2} \mathrm{SO}_{4}$ (Figure 1(A) and 1(C)) and in $0.1 \mathrm{M} \mathrm{KOH}$ (Figure 1(B) and 1(D)). Figure S6 show the LSV obtained for unmodified SPE and $424 \mu \mathrm{g} \mathrm{cm}^{-2}$ of CND-COOH and $\mathrm{CND}_{-\mathrm{CONH}}$ in deoxygenated solutions of $0.1 \mathrm{M} \mathrm{H}_{2} \mathrm{SO}_{4}(\mathrm{~A})$ and $0.1 \mathrm{M} \mathrm{KOH}(\mathrm{B})$. Initially it was important to benchmark the activity of the bare/unmodified SPE and Pt electrode in the $0.1 \mathrm{M} \mathrm{H}_{2} \mathrm{SO}_{4}$ and $0.1 \mathrm{M} \mathrm{KOH}$ solutions. Figure 1(A) shows that the bare/unmodified electrode SPE and the Pt electrode have an ORR onset and ORR peak current ( $\left.\mathrm{I}_{\mathrm{p}}\right)$ of $c a .-0.50 \mathrm{~V}(v s . \mathrm{SCE})$ and $-670 \mu \mathrm{A} \mathrm{cm} \mathrm{cm}^{-2}$, and $+0.48 \mathrm{~V}(v s$. SCE), and 724 $\mu \mathrm{A} \mathrm{cm}{ }^{-2}$ in oxygenated $0.1 \mathrm{M} \mathrm{H}_{2} \mathrm{SO}_{4}$, respectively. Whilst, in oxygenated $0.1 \mathrm{M} \mathrm{KOH}$ (see Figure 1(B)) these electrodes exhibited ORR onset and ORR peak currents $\left(I_{p}\right)$ of $0.38 \mathrm{~V}$ and $-566 \mu \mathrm{A} \mathrm{cm}^{-2}$, and $-0.04 \mathrm{~V}$ ( $v s . \mathrm{SCE}$ ) and $581 \mu \mathrm{A} \mathrm{cm}^{-2}$, respectively. In both cases, as expected, the Pt electrode displays the optimal ORR activity for reasons outlined in the introduction.

It is clear upon inspection of Figure $1(\mathrm{~A})$ that, in $0.1 \mathrm{M} \mathrm{H}_{2} \mathrm{SO}_{4}$, upon modification of a bare/unmodified SPE with increasing mass coverages of CND-COOH the ORR onset becomes less electronegative, shifting by $0.33 \mathrm{~V}$ to $c a$. $-0.17 \mathrm{~V}$ (vs. SCE) at 424 $\mu \mathrm{g} \mathrm{cm}^{-2} \mathrm{CND}-\mathrm{COOH}$ of mass coverage. In regards to the achievable current density, there is an initial decrease after $21 \mu \mathrm{g} \mathrm{cm}^{-2}$ mass modification of CND-COOH to $-468 \mu \mathrm{A} \mathrm{cm}^{-2}$. This is then followed by an increase in the achievable current density with incremental mass coverage increases of CND-COOH until it reaches a maxima of $814 \mu \mathrm{A}$ $\mathrm{cm}^{-2}$ at $424 \mu \mathrm{g} \mathrm{cm}^{-2}$. The initial decrease can be explained by less $\mathrm{O}_{2}$ adsorption on the CND-COOH modified electrode surface during the modification process compare with the high amount adsorbed in the high porosity SPE. When $0.1 \mathrm{M} \mathrm{KOH}$ is utilised as an electrolyte rather than $0.1 \mathrm{M} \mathrm{H}_{2} \mathrm{SO}_{4}$ a similar trend is observed, as can be observed in Figure 1(B). Upon analysis of this figure it is clear that modification of an SPE with CND- 
$\mathrm{COOH}$ resulted in a less electronegative ORR onset with a $424 \mu \mathrm{g} \mathrm{cm}^{-2}$ mass modification reducing the onset potential by $0.17 \mathrm{~V}$ to $c a$. $-0.28 \mathrm{~V}$ (vs. SCE) and increasing the achievable current density by $157 \mu \mathrm{A} \mathrm{cm}^{-2}$ to $c a$. $-723 \mu \mathrm{A} \mathrm{cm}^{-2}$.

Next, it was important to assess the ORR activity of SPEs modified with CND-CONH 2 in $0.1 \mathrm{M} \mathrm{H}_{2} \mathrm{SO}_{4}$ and $0.1 \mathrm{KOH}$. Figure $1(\mathrm{C})$ shows that modification of an SPE with CND$\mathrm{CONH}_{2}$ in $0.1 \mathrm{M} \mathrm{H}_{2} \mathrm{SO}_{4}$ enables the ORR to occur at a less electronegative overpotential compared to that of a bare/unmodified SPE, with an initial shift of $0.33 \mathrm{~V}$ to $c a$. $-0.26 \mathrm{~V}$ (vs. SCE) for the SPE modified with $21 \mu \mathrm{g} \mathrm{cm}^{-2}$ of $\mathrm{CND}-\mathrm{CONH}_{2}$. The magnitude of the shift correlates with the mass coverage of $\mathrm{CND}-\mathrm{CONH}_{2}$, as the largest mass/coverage modification (424 $\mu \mathrm{g} \mathrm{cm}^{-2}$ ) explored, results in the least electronegative ORR onset potential ( $-0.12 \mathrm{~V}$ (vs. SCE)) observed. Modification of an SPE with $\mathrm{CND}-\mathrm{CONH}_{2}$ does not however cause an increase in the achievable current density (see Figure $1(\mathrm{C})$ ). Figure (D) shows that when utilising a $0.1 \mathrm{KOH}$ electrolyte, the modification of an SPE with CND-CONH 2 produces a beneficial electrocatalytic response in regards to the ORR onset, reducing it by $0.08 \mathrm{~V}$ to $c a .-0.3 \mathrm{~V}$ ( $v s$. SCE) for all masses of modification. In regards to the achievable current densities, it is obvious from inspection of this figure that the addition of $21 \mu \mathrm{g} \mathrm{cm}^{-2}$ to an SPE increased the ORR peak by $64 \mu \mathrm{A} \mathrm{cm}^{-2}$ to $c a$. $-630 \mu \mathrm{A}$ $\mathrm{cm}^{-2}$. This initial increase in current density is followed by incremental decreases with further additions of $\mathrm{CND}^{-\mathrm{CONH}_{2}}$ until the maximal $424 \mu \mathrm{g} \mathrm{cm}^{-2}$ mass coverage is achieved and ORR peak current is $378 \mu \mathrm{A} \mathrm{cm}$. This decrease can be explained by an agglomeration of the nanomaterial in this acidic conditions, avoiding a good electrochemical connection between the bare electrode and the electrocatalyst nanodots.

Whilst none of the SPEs modified with varying mass coverages of CND-COOH or CND$\mathrm{CONH}_{2}$, outperform the Pt electrode (in either acidic or basic electrolyte), it is clear from the results described above, and Figure 1, that at specific CND-COOH or CND-CONH 2 mass coverages of SPEs, there is a significant increase in the observed ORR electrocatalytic activity (except for $\mathrm{CND}-\mathrm{CONH}_{2}$ in an acidic media, with regards to the achievable current, as it is observed to cause a decrease in magnitude of current density at all of the mass coverages explored).

\subsection{The ORR mechanism}


The results presented above show that upon the addition of CND-COOH or CND-CONH 2 to the surface of an SPE (within acidic or basic media) there is a beneficial ORR signal output. It is therefore essential to assess the ORR mechanism occurring at each of the modified surfaces. Tafel analysis is a common approach employed to deduce the number of electrons involved in the ORR electrochemical mechanism. ${ }^{46}$ For a full description of how Tafel analysis was performed, interested readers are directed towards the supporting information and Figure S7. Using the Tafel method, the number of electrons involved in the ORR mechanism of Pt, a bare/unmodified SPE and SPEs modified with 21, 42, 106, 212 and $424 \mu \mathrm{g} \mathrm{cm}^{-2}$ of CND-COOH or CND-CONH$H_{2}$ were deduced and presented in Table 2. As expected the ORR mechanism (in both acidic and basic media) for an Pt electrode occurs via the desirable 4 electron pathway $\left(\mathrm{O}_{2}\right.$ product), whereas the SPE causes the ORR to occur via the detrimental 2 electron pathway $\left(\mathrm{H}_{2} \mathrm{O}_{2}\right.$ product). In acid media, both CNDs, at all masses of SPE coverage, have a 2 electron pathway ORR mechanism, where $\mathrm{H}_{2} \mathrm{O}_{2}$ is the major reaction product. Table 2 shows that, in a basic electrolyte all of the SPEs modified with $\mathrm{CND}-\mathrm{CONH}_{2}$ had a ORR mechanism involving 2 electrons. The most promising results arise from the SPEs modified with CND-COOH within $0.1 \mathrm{M} \mathrm{KOH}$, where a desirable 4 electron pathway was observed for the ORR.

It was important to test the operational stability of the variant CND modified SPEs (in 0.1 $\mathrm{M} \mathrm{KOH}$ sat $\mathrm{O}_{2}$ ) as qualities such as durability and stability are essential criteria for industrial applications. The stability tests were carried out by immersing the CNDs/SPE in $\mathrm{O}_{2}$ saturated $0.1 \mathrm{M} \mathrm{KOH}$, under continuous stirring (in order ensure a constant $\mathrm{O}_{2}$ concentration profile over the electrodes surface for the duration of the test), with a constant applied potential of $-0.4 \mathrm{~V}$. The results of which are viewable in Figure S8(A). It is clear that both the CND-COOH or CND-CONH 2 modified SPE have an initial increase in their relative current output, likely a result of the activation of both materials in a basic media, until at 2 hours a maximum output is achieved after which there is a gradual decrease in current until 5 hours, this demonstrates the high stability of the two types of carbon nanodots when employed as oxygen reduction electrocatalyst. Note that previous studies have shown the surface of an SPE to be considerably rougher than more traditional carbon based electrodes, ${ }^{5}$ this surface roughness may allow of an anchoring effect for the CNDs, thereby preventing their dissolution into the electrolyte and meaning that the utilization of polymers such as Nafion, which are typically used to anchor the CNDs, are not necessary to retain the CNDs on the SPEs surface. ${ }^{34}$ Another consideration 
is the resistance of the CND-COOH and $\mathrm{CND}-\mathrm{CONH}_{2}$ to methanol poisoning, which has been shown to considerably reduce the ORR activity of platinum based electrocatalysts, the results of which can be observed in Figure S8(B). From inspection of this figure it is clear that upon the additional of a $1.5 \mathrm{M}$ methanol into a $\mathrm{O}_{2}$ saturated $0.1 \mathrm{M} \mathrm{KOH}$ cell (at 700 and again at 1200 seconds) there was an increase of $c a .25 \%$ in the relative, but both the $\mathrm{CND}-\mathrm{COOH}$ and $\mathrm{CND}-\mathrm{CONH}_{2}$ modified SPEs current returned to the baseline level within $c a$. 100 seconds. These results indicate that both the unique electrocatalysts explored herein exhibit remarkable methanol tolerance for ORR compared to traditional Pt catalyst in alkaline medium.

Electrochemical impedance spectroscopy (EIS) was next utilised in order to determine the impedance of the electrode system as the mass coverage of CND-COOH and CND$\mathrm{CONH}_{2}$ altered. Figure 2 shows the additional of the CNDs onto the surface of an SPE reduces the observed charge transfer resistance $(\Omega)$ this supports the interference that the CNDs improve an SPEs electrochemical response. The modification of a SPE with CND$\mathrm{COOH}$ (Figure 2(A) and 2(C)) resulted in a larger decrease in the $\Omega$ than a SPE modified with $\mathrm{CND}-\mathrm{CONH}_{2}$ (Figure $2 \mathrm{~B}$ and 2D) with the $\Omega$ difference between the bare and CND modified SPEs being most pronounced in acidic electrolyte. This indicates that whilst the CND-COOH allows the ORR to occur via a 4 electron pathway in a basic electrolyte it also increases the ORR activity of an SPE in $0.1 \mathrm{M} \mathrm{H}_{2} \mathrm{SO}_{4}$ electrolyte.

Clearly, from the above physicochemical characterisation and electrochemical testing both the $\mathrm{CNDs}$ variants (CND-COOH and $\mathrm{CND}-\mathrm{CONH}_{2}$ ) increase the ORR electrocatalytic activity of a SPE in $0.1 \mathrm{M} \mathrm{KOH}$ and $0.1 \mathrm{M} \mathrm{H}_{2} \mathrm{SO}_{4}$. Of particular interest is the application of CND-COOH in a basic electrolyte, as it is shown above to allow the ORR mechanism to occur via a desirable 4-electron pathway, whilst also displaying remarkable stability, in regards to current output, and methanol tolerance. 


\section{Conclusions}

We have herein reported the fabrication, physicochemical characterisation and application of CND-COOH and CND-CONH 2 modified SPEs towards the ORR in $0.1 \mathrm{M}$ $\mathrm{KOH}$ and $0.1 \mathrm{M} \mathrm{H}_{2} \mathrm{SO}_{4}$.

Both CND variants were shown to increase the ORR signal output, in regards to increasing the achievable current and decreasing the electronegativity of the ORR onset potential, of an SPE when drop-cast onto the electrodes surface. Except for CND-CONH 2 in an acidic media, which caused a decrease in the magnitude of the current density at all of the mass coverages explored. The most effective electrochemical configuration explored was an SPE modified with $424 \mu \mathrm{g} \mathrm{cm}^{-2}$ of CND-COOH in oxygenated $0.1 \mathrm{M}$ $\mathrm{KOH}$ that displayed an ORR peak current, onset potential of $-723 \mu \mathrm{A} \mathrm{cm} \mathrm{cm}^{-2}$ and ca. $-0.28 \mathrm{~V}$ (vs. SCE), respectively whilst also allowing the ORR mechanism to occur via a desirable 4 electron ORR pathway. This is a significant improvement in ORR signal output compared to a bare/unmodified SPE, which displayed a ORR peak current and onset potential of $-566 \mu \mathrm{A} \mathrm{cm}^{-2}$ and $-0.38 \mathrm{~V}$, respectively. Whilst causing the ORR to occur via the detrimental 2 electron pathway. The CND variants also displayed remarkable stability and methanol tolerance with no degradation being observed in the achievable current with the current returning to the baseline level within $100 \mathrm{~s}$ of exposure to a $1.5 \mathrm{M}$ solution of methanol. We suggest that the observed stability is a result of the CNDs becoming "anchored" onto the intrinsically rough surface of an SPE.

Future work to establish the effect of the CND variants upon the efficiency of a PEMFC would be of great interest. This work should have be focused upon exploring the interaction of CND variants with the PEMFCs triple phase boundary. The CND-COOH produced within this study offer a produce cheap, stable and effective alternative to platinum based cathode materials within alkaline PEMFCs, thusly making this technique for clean energy generation significantly more economically attractive. 


\section{Acknowledgements}

Funding from the Engineering and Physical Sciences Research Council (Reference: EP/N001877/1), British Council Institutional Grant Link (No. 172726574). E. MartínezPeriñán acknowledges funding from Comunidad de Madrid (NANOAVANSENS Program) for financial support. The Manchester Fuel Cell Innovation Centre is funded by the ERDF. 
Table 1. Carbon nanomaterials applied as ORR electrocatalyst indicating the heteroatom present in their structure.

\begin{tabular}{|c|c|c|c|c|c|c|c|}
\hline Carbon nanomaterial & Heteroatoms & Medium & $\begin{array}{l}\text { Supporting } \\
\text { electrode }\end{array}$ & $\begin{array}{c}\text { ORR } \\
\text { onset (V) }\end{array}$ & $\begin{array}{l}\text { Loading } \\
\text { of catalyst } \\
\left(\mu \mathrm{g} \mathrm{cm}^{-2}\right)\end{array}$ & $\begin{array}{c}\text { Number } \\
\text { electrons } \\
\text { ORR }\end{array}$ & Reference \\
\hline Mesoporous Graphene & $\mathrm{N}, \mathrm{S}$ & $\begin{array}{l}0.1 \mathrm{M} \\
\mathrm{KOH}\end{array}$ & $\begin{array}{l}\text { Glassy } \\
\text { Carbon }\end{array}$ & $\begin{array}{l}-0.06 v s \\
\mathrm{Ag} / \mathrm{AgCl}\end{array}$ & - & $3.3-3.6$ & 18 \\
\hline Carbon nanoplatelets & $\mathrm{N}, \mathrm{S}$ & $\begin{array}{l}0.1 \mathrm{M} \\
\mathrm{KOH}\end{array}$ & $\begin{array}{l}\text { Glassy } \\
\text { Carbon }\end{array}$ & $\begin{array}{c}0.86 v s . \\
\text { RHE }\end{array}$ & 420 & 3.80 & 20 \\
\hline Carbon nanoplatelets & $\mathrm{N}, \mathrm{S}$ & $\begin{array}{l}0.5 \mathrm{M} \\
\mathrm{H}_{2} \mathrm{SO}_{4}\end{array}$ & $\begin{array}{l}\text { Glassy } \\
\text { Carbon }\end{array}$ & $\begin{array}{l}0.78 v s . \\
\text { RHE }\end{array}$ & 280 & 3.92 & 20 \\
\hline Carbon nanotubes & $\mathrm{N}$ & $\begin{array}{l}0.1 \mathrm{M} \\
\mathrm{KOH}\end{array}$ & $\begin{array}{l}\text { Glassy } \\
\text { Carbon }\end{array}$ & $\begin{array}{l}-0.22 v s \\
\mathrm{Ag} / \mathrm{AgCl}\end{array}$ & - & 3.90 & 25 \\
\hline Graphene & $\mathrm{B}, \mathrm{N}$ & $\begin{array}{l}0.1 \mathrm{M} \\
\mathrm{KOH}\end{array}$ & $\begin{array}{l}\text { Glassy } \\
\text { Carbon }\end{array}$ & $\begin{array}{c}-0.18 v s . \\
\text { SCE }\end{array}$ & - & $\approx 4$ & 26 \\
\hline Graphene Quantum Dots & $\mathrm{N}, \mathrm{O}$ & $\begin{array}{l}0.1 \mathrm{M} \\
\mathrm{KOH}\end{array}$ & $\begin{array}{l}\text { Glassy } \\
\text { Carbon }\end{array}$ & $\begin{array}{l}-0.16 v s \\
\mathrm{Ag} / \mathrm{AgCl}\end{array}$ & 283 & $3.6-4.4$ & 27 \\
\hline Graphene & $\mathrm{N}$ & $\begin{array}{l}0.1 \mathrm{M} \\
\mathrm{KOH}\end{array}$ & $\begin{array}{c}\text { CVD } \\
\text { Graphene } \\
\text { over } \mathrm{Cu} \text { foil }\end{array}$ & $\begin{array}{c}-0.3 \text { vs. } \\
\mathrm{Ag} / \mathrm{AgCl}\end{array}$ & - & $\approx 2$ & 28 \\
\hline $\begin{array}{l}\text { Multiwalled Carbon } \\
\text { Nanotubes }\end{array}$ & $\mathrm{N}$ & $\begin{array}{l}0.1 \mathrm{M} \\
\mathrm{KOH}\end{array}$ & $\begin{array}{l}\text { Glassy } \\
\text { Carbon }\end{array}$ & $\begin{array}{c}-0.2 v s \\
\mathrm{Ag} / \mathrm{AgCl}\end{array}$ & 336 & 3.53 & 47 \\
\hline Carbon Nanotube Cups & $\mathrm{N}$ & $\begin{array}{l}0.1 \mathrm{M} \\
\mathrm{KOH}\end{array}$ & $\begin{array}{l}\text { Glassy } \\
\text { Carbon }\end{array}$ & $\begin{array}{l}-0.30 v s \\
\mathrm{Ag} / \mathrm{AgCl}\end{array}$ & 20.2 & 2.82 & 48 \\
\hline Graphene & $\mathrm{B}, \mathrm{N}$ & $\begin{array}{l}0.1 \mathrm{M} \\
\mathrm{KOH}\end{array}$ & $\begin{array}{l}\text { Glassy } \\
\text { Carbon }\end{array}$ & $\begin{array}{l}0.75 \text { vs. } \\
\text { RHE }\end{array}$ & 100 & 3.92 & 49 \\
\hline Fullerene & $\mathrm{O}$ & $\begin{array}{c}0.25 \mathrm{M} \\
\mathrm{PBS} \mathrm{pH} \\
7.4\end{array}$ & - & $\begin{array}{c}0.35 v s . \\
\mathrm{Ag} / \mathrm{AgCl}\end{array}$ & - & - & 50 \\
\hline Carbon nanodots & $\mathrm{N}$ & $\begin{array}{l}0.1 \mathrm{M} \\
\mathrm{KOH}\end{array}$ & $\begin{array}{l}\text { Glassy } \\
\text { Carbon }\end{array}$ & $\begin{array}{l}-0.06 v s \\
\mathrm{Ag} / \mathrm{AgCl}\end{array}$ & 202 & $3.75-3.95$ & 32 \\
\hline $\begin{array}{c}\text { Carbon } \\
\text { Nanodots@Nanospheres }\end{array}$ & $\mathrm{N}$ & $\begin{array}{l}0.1 \mathrm{M} \\
\mathrm{KOH}\end{array}$ & $\begin{array}{l}\text { Glassy } \\
\text { Carbon }\end{array}$ & $\begin{array}{l}-0.08 v s \\
\mathrm{Ag} / \mathrm{AgCl}\end{array}$ & 72 & $3.68-3.95$ & 34 \\
\hline carbon nanoparticles & $\mathrm{N}$ & $\begin{array}{l}0.1 \mathrm{M} \\
\mathrm{KOH}\end{array}$ & $\begin{array}{l}\text { Glassy } \\
\text { Carbon }\end{array}$ & $\begin{array}{l}-0.143 v s \\
\mathrm{Ag} / \mathrm{AgCl}\end{array}$ & 400 & $2.56-3.02$ & 51 \\
\hline Carbon nanodots & $-\mathrm{OH}$ & $\begin{array}{l}0.1 \mathrm{M} \\
\mathrm{KOH}\end{array}$ & $\begin{array}{l}\text { Screen- } \\
\text { printed } \\
\text { electrode }\end{array}$ & $\begin{array}{c}-0.28 \mathrm{~V} \\
(v s . \mathrm{SCE})\end{array}$ & 424 & 3.8 & This Work \\
\hline
\end{tabular}


Table 2. Tafel slope and electron number exchange during the oxygen reduction reaction in $0.1 \mathrm{M} \mathrm{KOH}$ and $0.1 \mathrm{M} \mathrm{H}_{2} \mathrm{SO}_{4}$ saturated $\mathrm{O}_{2}$ obtained from the LSV for bare SPE, CND$\mathrm{COOH} / \mathrm{SPE}$ and CND-CONH${ }_{2} / \mathrm{SPE}$. Scan rate: $25 \mathrm{mV} \mathrm{s}^{-1}$.

\begin{tabular}{|c|c|c|c|c|}
\hline \multirow[b]{2}{*}{ Electrode } & \multicolumn{2}{|c|}{ 0.1 M КОН Saturated $\mathrm{O}_{2}$} & \multicolumn{2}{|c|}{$0.1 \mathrm{M} \mathrm{H}_{2} \mathrm{SO}_{4}$ Saturated $\mathrm{O}_{2}$} \\
\hline & $\begin{array}{l}\text { Tafel slope } \\
\text { (mV/dec) }\end{array}$ & $\begin{array}{c}\text { number of } \\
\text { electrons }\end{array}$ & $\begin{array}{l}\text { Tafel slope } \\
\text { (mV/dec) }\end{array}$ & $\begin{array}{c}\text { number of } \\
\text { electrons }\end{array}$ \\
\hline SPE & 37.66 & 3.3 & 98.61 & 1.9 \\
\hline $21 \mu \mathrm{g} \mathrm{cm}^{-2} \mathrm{CND}-\mathrm{CONH}_{2} / \mathrm{SPE}$ & 38.80 & 3.1 & 92.49 & 1.7 \\
\hline $42 \mu \mathrm{g} \mathrm{cm}^{-2} \mathrm{CND}^{-\mathrm{CONH}_{2} / \mathrm{SPE}}$ & 39.85 & 2.9 & 90.02 & 1.7 \\
\hline $106 \mu \mathrm{g} \mathrm{cm}^{-2} \mathrm{CND}-\mathrm{CONH}_{2} / \mathrm{SPE}$ & 43.87 & 2.3 & 88.81 & 1.7 \\
\hline $212 \mu \mathrm{g} \mathrm{cm}^{-2} \mathrm{CND}-\mathrm{CONH}_{2} / \mathrm{SPE}$ & 47.34 & 2.1 & 86.89 & 1.6 \\
\hline $424 \mu \mathrm{g} \mathrm{cm}^{-2} \mathrm{CND}-\mathrm{CONH}_{2} / \mathrm{SPE}$ & 49.56 & 1.7 & 88.42 & 1.8 \\
\hline $21 \mu \mathrm{g} \mathrm{cm}^{-2} \mathrm{CND}-\mathrm{COOH} / \mathrm{SPE}$ & 39.74 & 3.0 & 92.53 & 1.4 \\
\hline $42 \mu \mathrm{g} \mathrm{cm}^{-2} \mathrm{CND}-\mathrm{COOH} / \mathrm{SPE}$ & 35.83 & 3.2 & 98.52 & 1.4 \\
\hline $106 \mu \mathrm{g} \mathrm{cm}^{-2} \mathrm{CND}-\mathrm{COOH} / \mathrm{SPE}$ & 32.77 & 3.5 & 102.20 & 1.5 \\
\hline $212 \mu \mathrm{g} \mathrm{cm}^{-2} \mathrm{CND}-\mathrm{COOH} / \mathrm{SPE}$ & 34.19 & 3.6 & 103.29 & 1.6 \\
\hline $424 \mu \mathrm{g} \mathrm{cm}^{-2} \mathrm{CND}-\mathrm{COOH} / \mathrm{SPE}$ & 34.74 & 3.8 & 100.67 & 1.7 \\
\hline Pt disc electrode & 43.46 & 4.4 & 39.87 & 3.70 \\
\hline
\end{tabular}


Figure 1. LSV of CND modified SPEs with increasing amounts of CND-COOH (A and B) and $\mathrm{CND}-\mathrm{CONH}_{2}\left(\mathrm{C}\right.$ and D) in $0.1 \mathrm{M} \mathrm{H}_{2} \mathrm{SO}_{4}(\mathrm{~A}$ and $\mathrm{C}$ ) and in $0.1 \mathrm{M} \mathrm{KOH}$ (B and D) saturated with $\mathrm{O}_{2}$ in both cases. Scan rate: $25 \mathrm{mV} \mathrm{s}^{-1}$. Oxygen reduction peak potential of Pt disc electrode ( $\nabla$ ), bare SPE (•) and CNDs modified SPE (CND-COOH(•) and

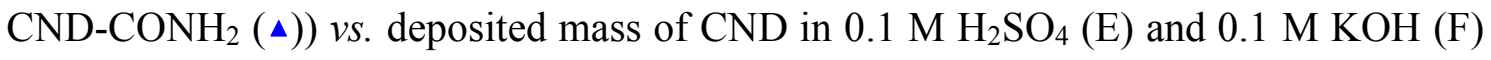
saturated with $\mathrm{O}_{2}$ in both cases.

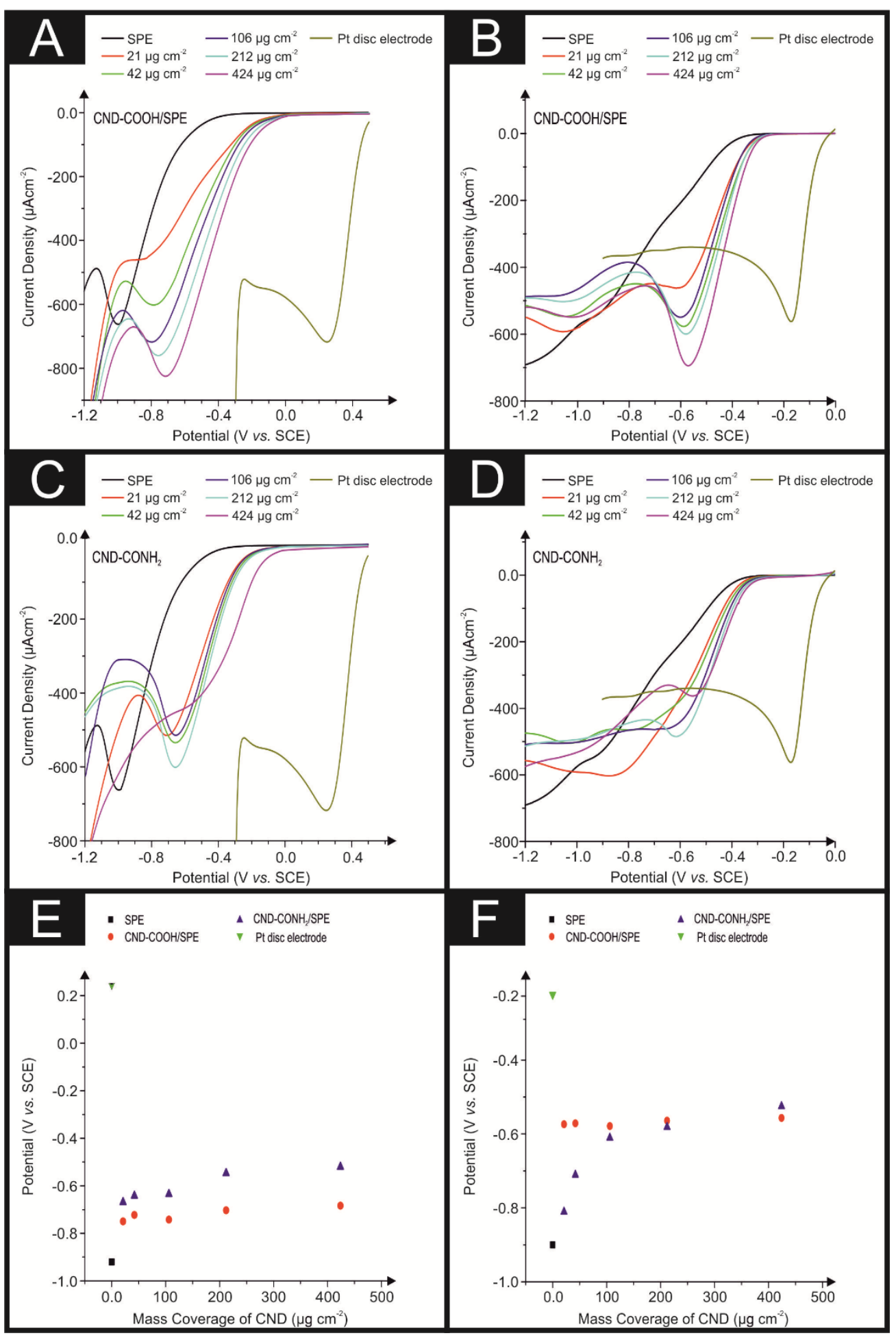


Figure 2. Nyquist plots (applied voltage $E=-0.4 \mathrm{~V}$ vs. SCE, using an amplitude of 0.05 $\mathrm{V}$ and frequencies range of 0.1 to $100000 \mathrm{~Hz}$ ) for CND-COOH/SPE (A and C) and CND$\mathrm{CONH}_{2} / \mathrm{SPE}(\mathrm{B}$ and $\mathrm{D})$ in $0.1 \mathrm{M} \mathrm{H}_{2} \mathrm{SO}_{4}$ sat $\mathrm{O}_{2}(\mathrm{~A}$ and $\mathrm{B})$ and $0.1 \mathrm{M} \mathrm{KOH}$ sat $\mathrm{O}_{2}(\mathrm{C}$ and D).

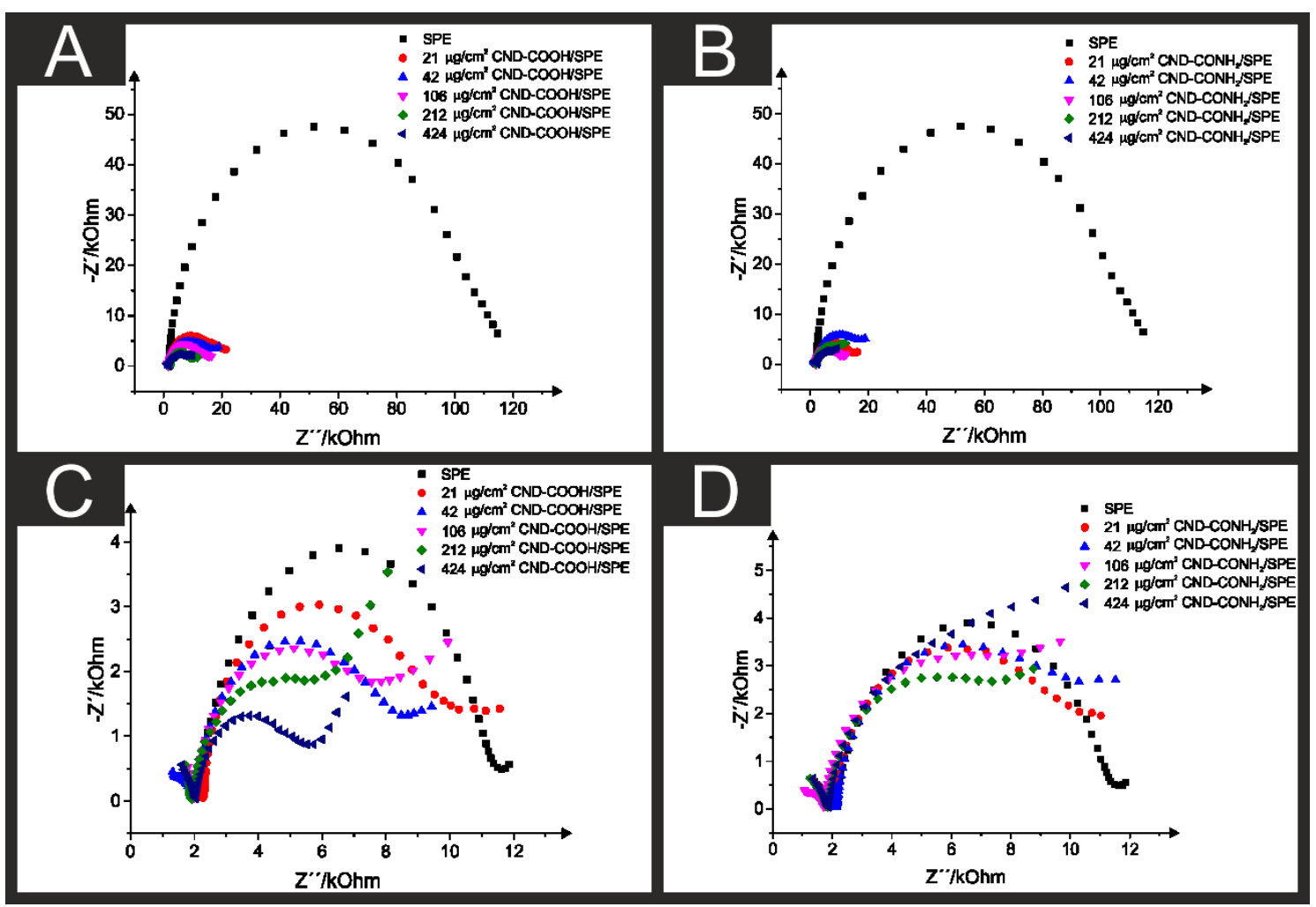


Electronic Supporting Information (ESI) for the following publication:

\section{Carbon Nanodots as Electrocatalysts towards the Oxygen Reduction Reaction}

Emiliano Martínez-Periñán, ${ }^{1,2}$ Iria Bravo, ${ }^{1,3}$ Samuel J. Rowley-Neale, ${ }^{2,4}$ Encarnación Lorenzo, ${ }^{1,3}$ and Craig E. Banks ${ }^{2,4 *}$

${ }^{1}$ : Departamento de Química Analítica y Análisis Instrumental, Universidad Autónoma de Madrid, 28049, Madrid, Spain.

2: Faculty of Science and Engineering, Manchester Metropolitan University, Chester Street, Manchester M1 5GD, UK.

3. IMDEA-Nanoscience, Faraday 9, Campus Cantoblanco-UAM, 28049 Madrid, Spain.

4: Fuel Cell Innovation Center, Manchester Metropolitan University, Chester Street, Manchester M1 5GD, UK.

*To whom correspondence should be addressed.

Email: c.banks@mmu.ac.uk; Tel: ++(0)1612471196; Fax: ++(0)1612476831

Website: www.craigbanksresearch.com 


\section{Characterisation Equipment Specifications}

DLS analysis was carried out at $25{ }^{\circ} \mathrm{C}$ with a VASCO particle size analyzer from Cordouan Technologies. XPS measures were carried out with AXIS Supra XPS photoelectron spectrometer using an $\mathrm{Al}(1486.6 \mathrm{eV}) \mathrm{X}$-ray source operating at $300 \mathrm{~W}$ for survey scans and $450 \mathrm{~W}$ for narrow scans. Al X-rays were monochromated using a 500 $\mathrm{mm}$ Rowland circle quartz crystal X-ray mirror. The angle between X-ray source and the analyser (magic angle) was 54.7 . A $165 \mathrm{~mm}$ mean radius hemispherical sector analyser was used as electron energy analyser, operating in fixed analyser transmission mode, pass energy $160 \mathrm{eV}$ for survey scans and $40 \mathrm{eV}$ narrow scans. Delay line detector with multichannel plate was used as detector. Fourier transform infrared spectroscopy (FT-IR) (Nicolet 380 Smart iTR, Waltham, USA) used diamond attenuated total reflection (ATR) diamond detector. CNDs samples (CND-COOH and $\mathrm{CND}-\mathrm{CONH}_{2}$ ) were dried and resuspended in methanol. Few drops of methanol CNDs suspensions were deposited in the equipment, letting methanol to evaporate complete and FT-IR spectrums were obtained. Transmission electron microscopy (TEM) pictures were obtained using a JEOL JEM 2100 electron microscope. Lacey carbon support film copper grids (400 Mesh) (ELECTRON MICROSCOPY SCIENCES) were used in TEM characterization. Scanning electron microscopy (SEM) images were obtained using a JEOL JSM-5600LV model. Raman spectroscopy was performed using a 'Renishaw InVia' spectrometer with a confocal microscope (x20 objective) spectrometer with an argon laser $(514.3 \mathrm{~nm}$ excitation) at a very low laser power level $(1.2 \mathrm{~mW})$ to avoid any heating effects. Spectra were recorded using a 10-second exposure time for 3 accumulations. 


\section{Physicochemical characterization of the CND-CONH 2 and CND-COOH}

The FT-IR spectrum for the CND-COOH is presented in Figure S2A, in this figure the carboxyl group is clearly identifiable via the broad band around $3438 \mathrm{~cm}^{-1}$ associated with the stretch of $\mathrm{O}-\mathrm{H}$. The bands at 1600 and $1362 \mathrm{~cm}^{-1}$ were associated to $\mathrm{C}=\mathrm{C}$ doublebond stretching vibrations and C-H vibrations, respectively. Figure S2B displays the FTIR spectrum for the $\mathrm{CND}-\mathrm{CONH}_{2}$. The broad band observed at $c a .3280 \mathrm{~cm}^{-1}$ is assigned to $\mathrm{O}-\mathrm{H}$ stretching, which indicated functional $-\mathrm{OH}$ groups or adsorbed water. The stretching vibrations at $1636 \mathrm{~cm}^{-1}$ and $1534 \mathrm{~cm}^{-1}$ are attributed to amide $\mathrm{C}=\mathrm{O}$ stretch and $\mathrm{N}-\mathrm{H}$ vibrations, respectively. C-H stretching in the $2878 \mathrm{~cm}^{-1}$ region and C-OH/C-O-C stretching at $1050 \mathrm{~cm}^{-1}$ are also observed, typical of the ethylene glycol moiety. It should be noted that that Table S1 shows that there is an unexpected high atomic concentration of sodium, it is likely the case that this has arose due to lab contamination or an impurity within the stock CND leading to sodium residues being detected.

A high resolution structure XPS analysis was performed, focusing on the $\mathrm{C} 1 \mathrm{~s}, \mathrm{~N}$ 1s and $\mathrm{O}$ 1s regions of both CNDs variants. The results of which are viewable in Figure S4. The CND-COOH high resolution analysis for the $\mathrm{C} 1 \mathrm{~s}$ region (see Figure $\mathrm{S} 4(\mathrm{~B})$ shows the main binding energy (BE) peaks at $285.1 \mathrm{eV}$ and $287.0 \mathrm{eV}$ corresponding to aliphatic carbons and to carbons in $\mathrm{C}=\mathrm{O}, \mathrm{C}-\mathrm{O}-\mathrm{H}$ and $\mathrm{C}-\mathrm{O}-\mathrm{C}$ functional groups ${ }^{52,53}$. Figure $\mathrm{S} 4(\mathrm{C})$ shows the $\mathrm{N}$ 1s region where a dominant peak at $407.5 \mathrm{eV}$ is observable, which correspond with $\mathrm{N}$ in nitrate form. This can be explained by the last synthesis step that is carried out in nitric acid, which leaves a residue of adsorbed ions onto the carbon nanodots surface $^{54}$. Even so the peaks around 400.1 and $399.0 \mathrm{eV}$ could be assigned to $\mathrm{N}$ with SP2 and SP3 bonds with carbons ${ }^{55}$, there is a possibility that this lead to the generation of nitrogen functional groups. However the density of such groups is likely to be sparse, if at all. The O-1s XPS spectrum in Figure S4(D) shows 3 bands at 531.4, 532.91 and 535.76

$\mathrm{eV}$, these correlate to the $\mathrm{C}=\mathrm{O}, \mathrm{C}-\mathrm{O}$ and $\mathrm{O}-\mathrm{H}$ groups previously reported by Bai et al. ${ }^{56}$. In the case of CND-CONH 2 the $\mathrm{C} 1 \mathrm{~s}$ region (see Figure $\mathrm{S} 4(\mathrm{~F})$ show a broad band around $286.5 \mathrm{eV}$, this can be deconvoluted to distinguish 4 different peaks at 285.1, 286.4, 287.0 and $288.3 \mathrm{eV}$. The highest contribution in this spectrum is made by the band at 286.4 , which is ascribed to C-N species. ${ }^{57}$ An additional contribution is observed at $285.1 \mathrm{eV}$ (corresponding to aliphatic carbons ${ }^{52}$ ) and 287.0 corresponding to $\mathrm{C}=\mathrm{O}$, even so there are some contribution of $288.3 \mathrm{eV}$ related with $\mathrm{N}-\mathrm{C}-=\mathrm{O} .{ }^{57}$ This confirms the presence of amides in the carbon nanodots surface. $\mathrm{N}$ 1s region shows a bands with contribution of 
$399.8(-\mathrm{O}=\mathrm{C}-\mathrm{N}-\mathrm{H})$ and $401.7(\mathrm{C}-\mathrm{N})$, viewable in Figure $\mathrm{S}(4 \mathrm{G}) .{ }^{57,58}$ Finally in the $\mathrm{O} 1 \mathrm{~s}$ region of the $\mathrm{CND}-\mathrm{CONH}_{2}$ (see Figure $\mathrm{S} 4(\mathrm{H})$ a single band at $532.4 \mathrm{eV}$ is observed and can be assigned to $\mathrm{C}=\mathrm{O}$ band ${ }^{56}$.

\section{Tafel analysis of the ORR mechanism}

Using the following equation: $\frac{\delta \ln (I)}{\delta E}=\frac{\left(\alpha n^{\prime}\right) F}{R T}$, where the slope of the $\ln (\mathrm{I}) \mathrm{vs.}$ Ep (V) plot is $\delta \ln (\mathrm{I}) / \delta \mathrm{E}$ (see Figure S6), $\alpha$ is the electron transfer coefficient, $\mathrm{F}$ is the Faraday constant, $\mathrm{n}^{\prime}$ is the number of electrons transferred in the rate determining step, $\mathrm{R}$ is the gas constant and $\mathrm{T}$ is the temperature of the solution temperature in kelvin. ${ }^{46}$ Literature has previously suggested that the rate determining step involving the transfer of the first electron is electrochemically irreversible resulting in $\mathrm{n}^{\prime}$ being $1,{ }^{59}$ with $\alpha \mathrm{n}^{\prime}$ values for SPEs across all masses of modification were deduced. Using these values, the number of electrons involved in the ORR reaction mechanism, n, was deduce using the $\alpha \mathrm{n}^{\prime}$ calculated from the Tafel equation (see above) and the Randles-Ševćik equation for an irreversible electrochemical process: ${ }^{60}$

$$
I_{P}^{I r r e v}= \pm 0.496\left(\alpha n^{\prime}\right)^{1 / 2} n F A C(F D v / R T)^{1 / 2}
$$

where $C$ is concentration, which is assumed for the oxygen saturated solution $(0.9 \mathrm{mM})$, a literature diffusion coefficient value of $2.0 \times 10^{-5} \mathrm{~cm}^{2} \mathrm{~s}^{-1}$ is assumed in the case of acid media, ${ }^{61}$ and $A$ is the geometric area of the electrode. In the case basic media $(0.1 \mathrm{M}$ $\mathrm{KOH}) C$ is $1.2 \mathrm{mM}$ and a diffusion coefficient value of $1.9 \times 10^{-5} \mathrm{~cm}^{2} \mathrm{~s}^{-1} .33$ 
Table S1. XPS results of COOH-CNDs and $\mathrm{CONH}_{2}-\mathrm{CNDs}$.

\begin{tabular}{ccccccccc}
\hline \multicolumn{9}{c}{ COOH-CNDs } \\
& $\begin{array}{c}\text { Atomic } \\
\text { conc. [\%] }\end{array}$ & $\begin{array}{c}\text { Error } \\
{[\%]}\end{array}$ & $\begin{array}{c}\text { Mass } \\
\text { conc. [\%] }\end{array}$ & $\begin{array}{c}\text { Error } \\
{[\%]}\end{array}$ & $\begin{array}{c}\text { Atomic } \\
\text { conc. [\%] }\end{array}$ & $\begin{array}{c}\text { Error } \\
{[\%]}\end{array}$ & $\begin{array}{c}\text { Mass } \\
\text { conc. [\%] }\end{array}$ & $\begin{array}{c}\text { Error } \\
{[\%]}\end{array}$ \\
\hline O 1s & 37,74 & 0,17 & 40,93 & 0,19 & 26,58 & 0,14 & 31,75 & 0,17 \\
N 1s & 4,55 & 0,17 & 4,32 & 0,16 & 9,37 & 0,13 & 9,8 & 0,14 \\
C 1s & 47,8 & 0,19 & 38,91 & 0,19 & 63,19 & 0,17 & 56,66 & 0,21 \\
Si 2p & 1,16 & 0,11 & 2,21 & 0,21 & 0,84 & 0,1 & 1,76 & 0,22 \\
Na 1s & 8,75 & 0,08 & 13,63 & 0,12 & 0,02 & 0,03 & 0,03 & 0,05 \\
\hline
\end{tabular}


Figure S1. Dynamic light scattering (DLS) histogram of (A) CND-COOH and (B) CND-CONH 2 . (C) DLS Curves of CND-COOH (red) and CND-CONH 2 (black).

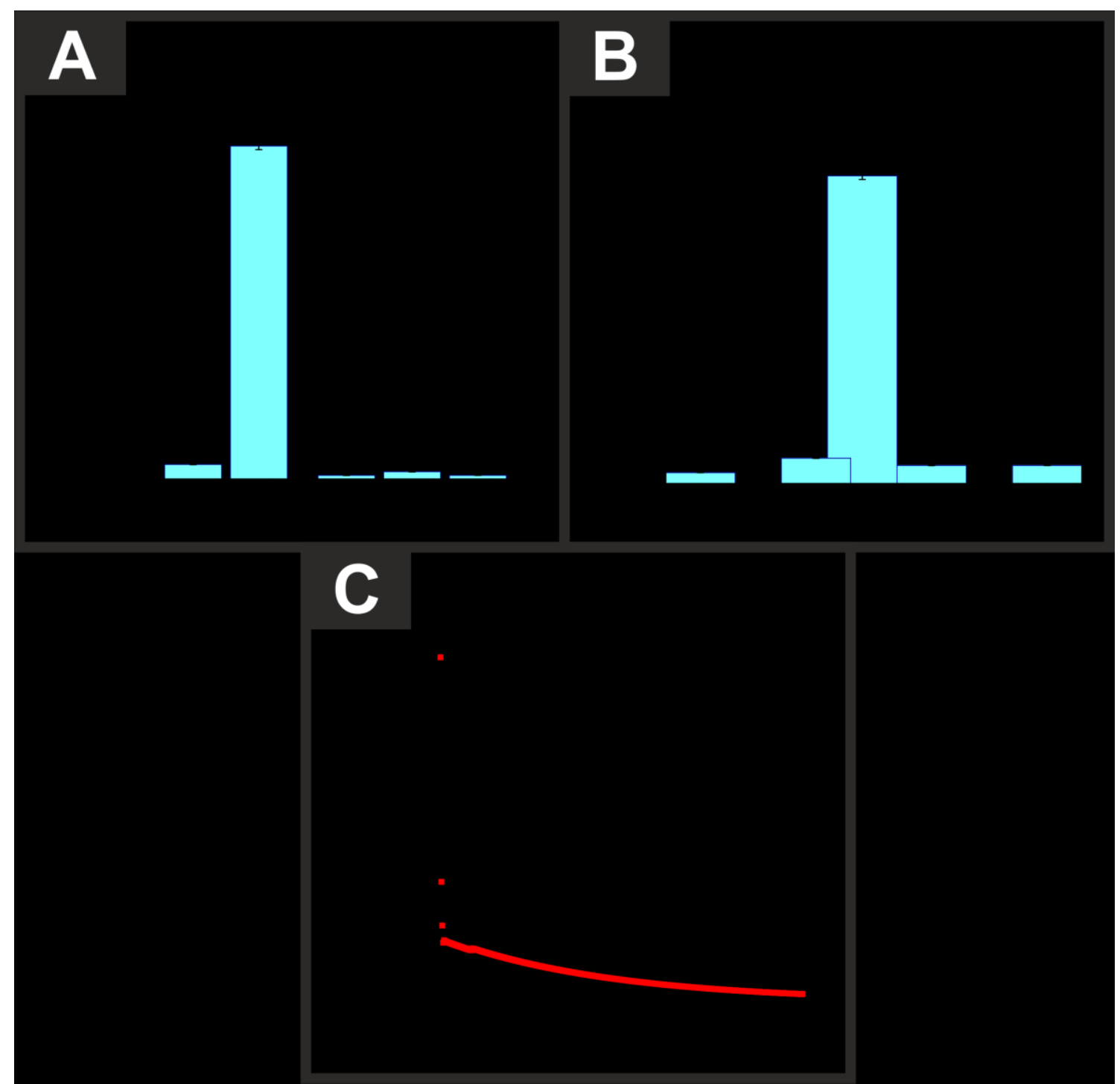


Figure S2. TEM images of the fabricated CND-COOH, (A) scale bar: $50 \mathrm{~nm}$; (B) scale bar: $20 \mathrm{~nm}$ and fabricated CND-CONH${ }_{2},(C)$ scale bar: $50 \mathrm{~nm}$; (D) scale bar: $20 \mathrm{~nm}$.

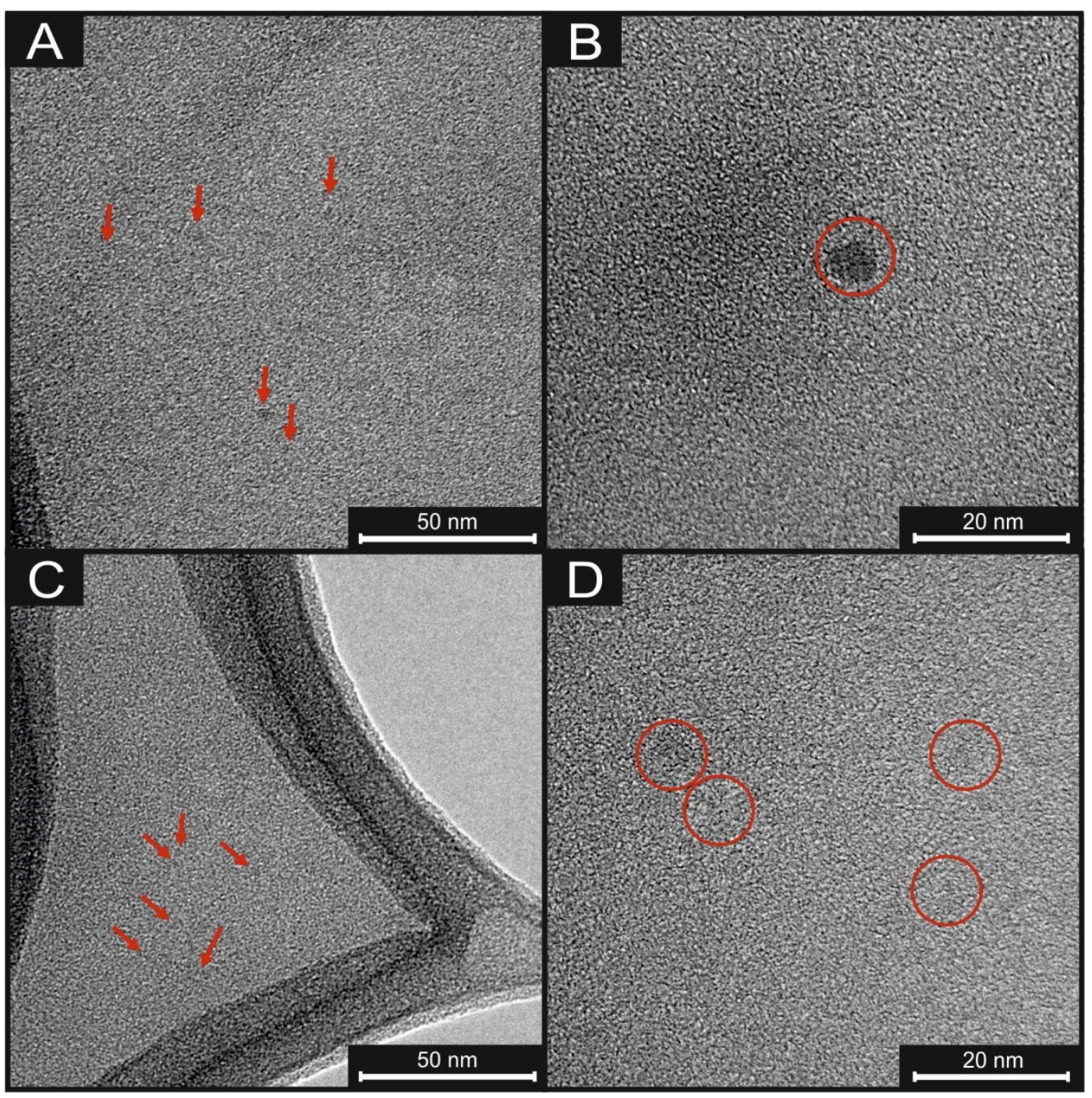


Figure S3. FT-IR spectra of CND-COOH (A) and CND-CONH $2(B)$.

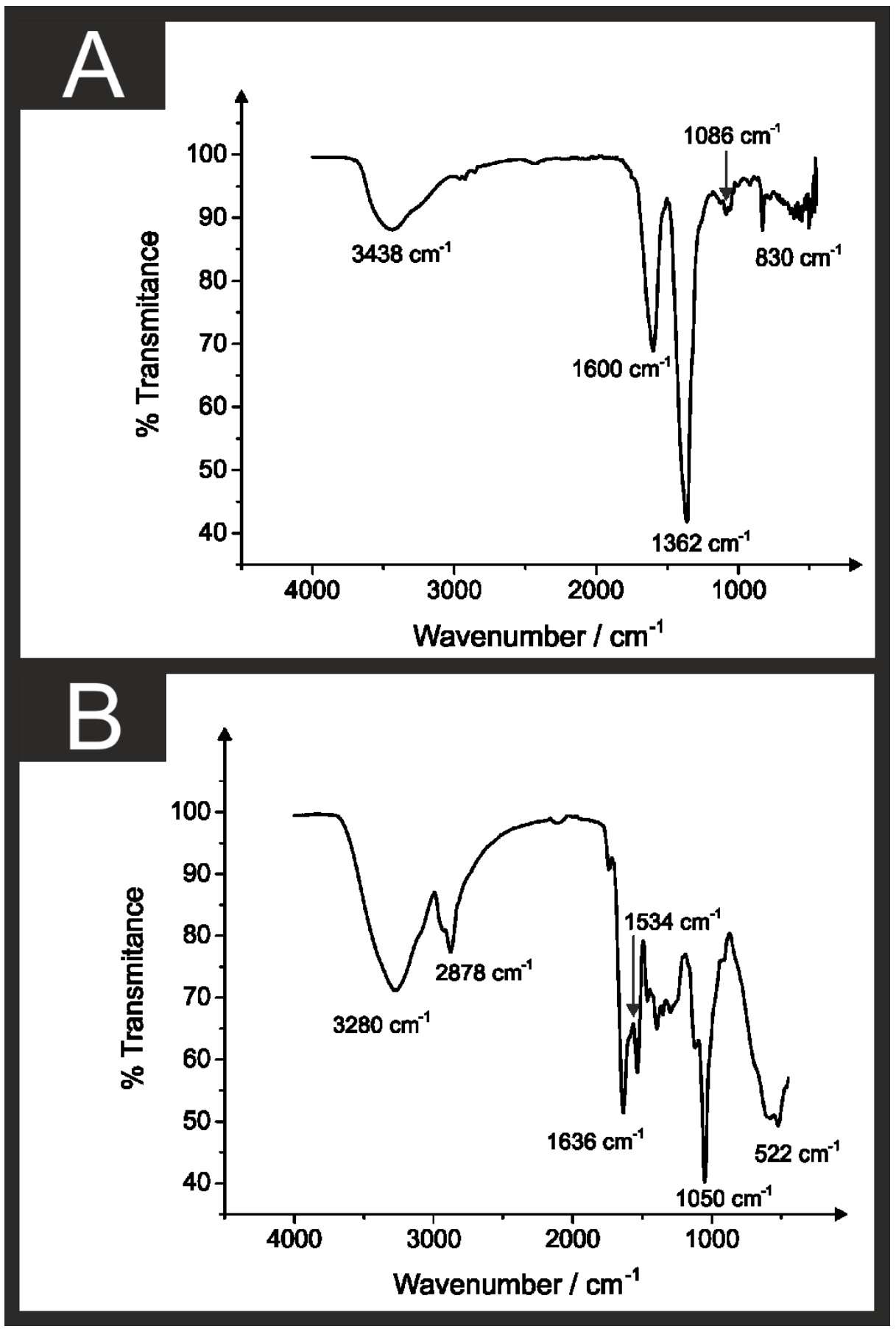


Figure S4. XPS spectrums of CND-COOH (A) whole spectrum, (B) C 1s region of A, (C), $\mathrm{N}$ 1s region of $\mathrm{A}$, (D) $\mathrm{O} 1 \mathrm{~s}$ region of $\mathrm{A}$ and $\mathrm{CND}-\mathrm{CONH}_{2}(\mathrm{E})$ whole spectrum, $(\mathrm{F}) \mathrm{C}$ 1s region of $\mathrm{E},(\mathrm{G}), \mathrm{N}$ 1s region of $\mathrm{E},(\mathrm{H}) \mathrm{O}$ 1s region of $\mathrm{E}$.

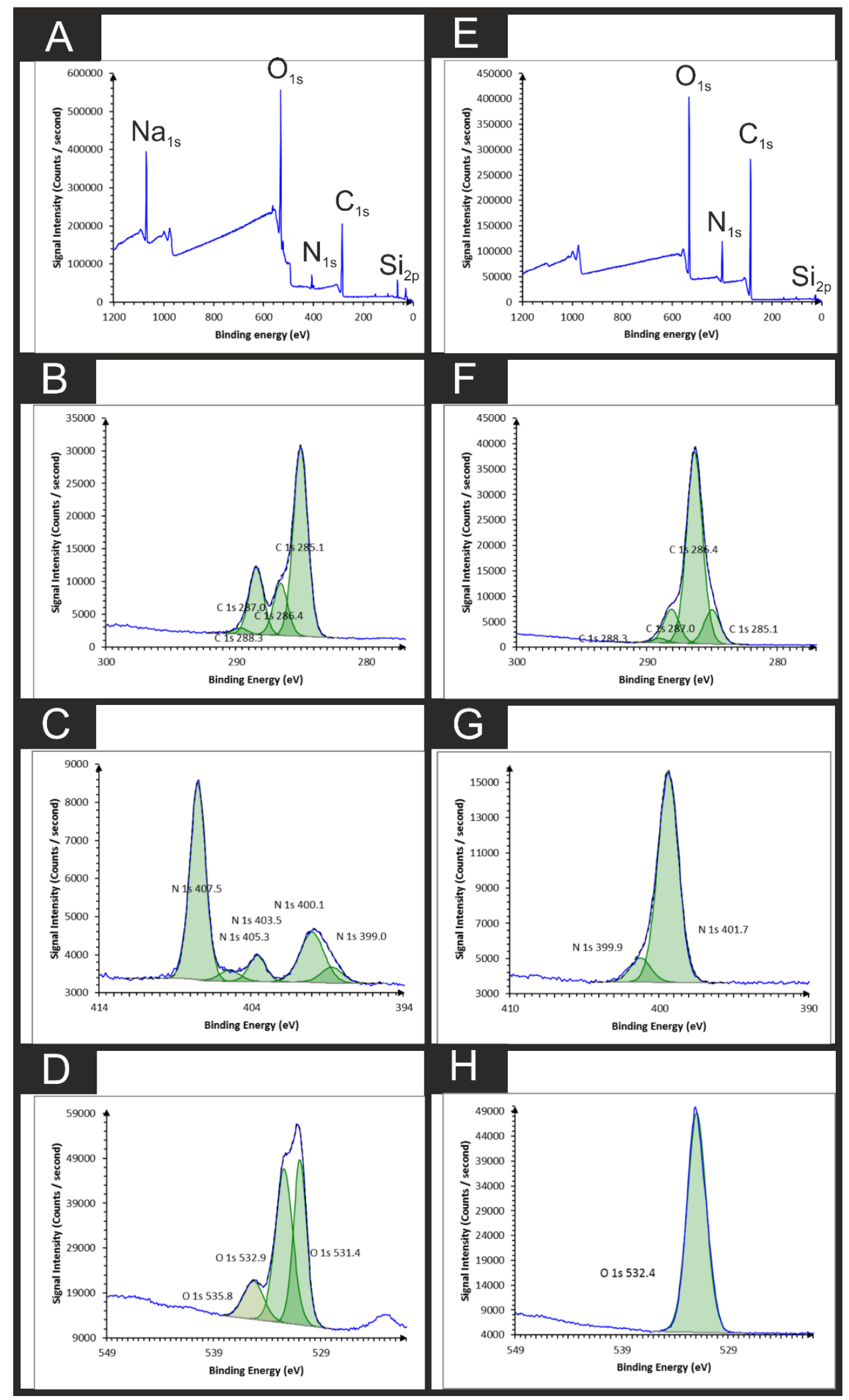


Figure S5. SEM images of (A) Bare SPE, (B) $212 \mu \mathrm{g} \mathrm{cm}^{-2}$ CND-COOH/SPE. (C) 212 $\mu \mathrm{g} \mathrm{cm}^{-2} \mathrm{CND}-\mathrm{CONH}_{2} / \mathrm{SPE}$.

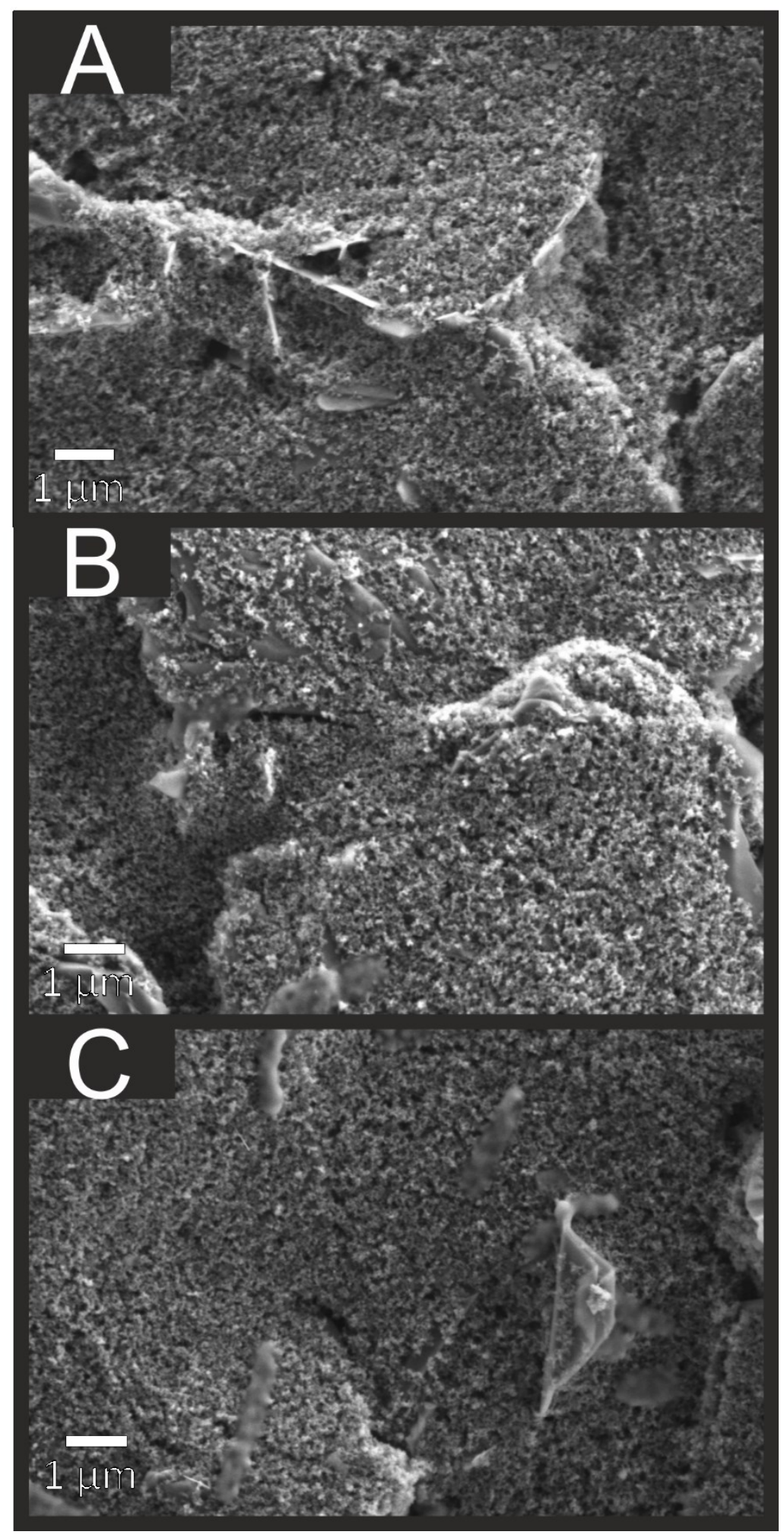


Figure S6. LSV at $25 \mathrm{mV} \mathrm{s}^{-1}$ of CND modified SPEs with $424 \mu \mathrm{g} \mathrm{cm}^{-2}$ of CND-COOH and $\mathrm{CND}-\mathrm{CONH}_{2}$ in $0.1 \mathrm{M} \mathrm{H}_{2} \mathrm{SO}_{4}(\mathrm{~A})$ and in $0.1 \mathrm{M} \mathrm{KOH}(\mathrm{B})$ without $\mathrm{O}_{2}$ in both cases.

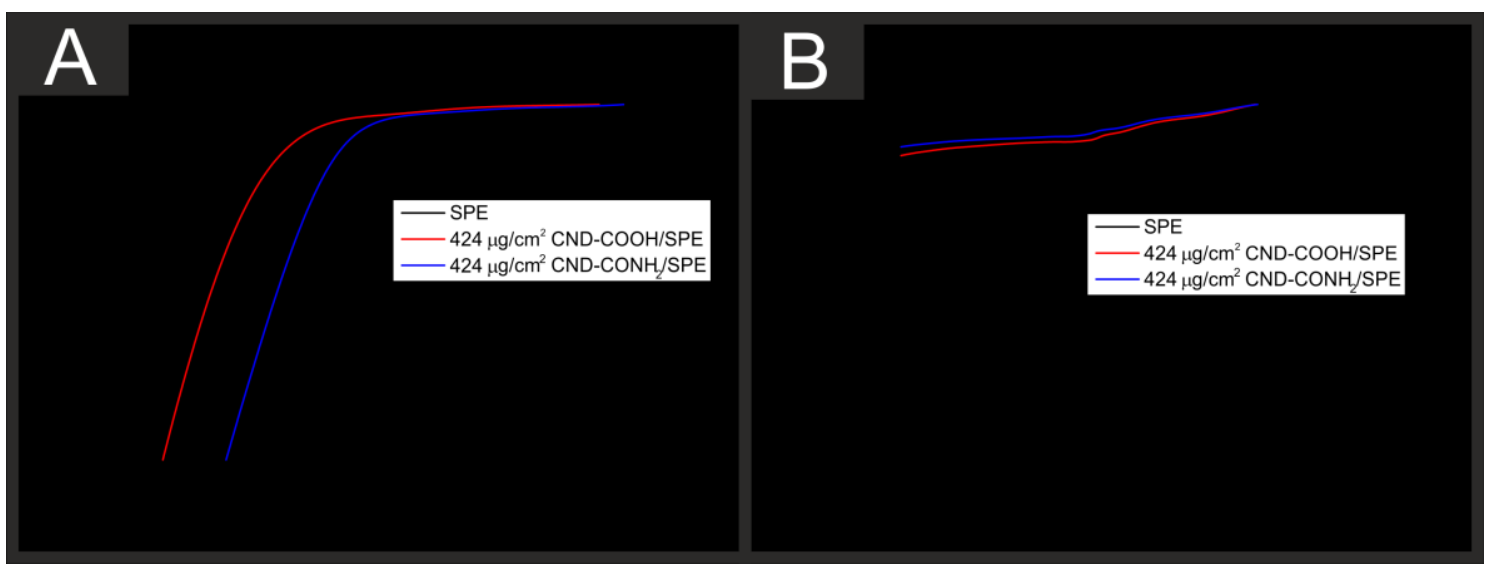


Figure S7. Tafel slopes corresponding to the faradaic region of the LSVs for Pt disc electrode (•), bare SPE (•), $424 \mu \mathrm{g} \mathrm{cm}^{-2} \mathrm{CND}-\mathrm{COOH} / \mathrm{SPE}(\bullet)$, and $424 \mu \mathrm{g} \mathrm{cm}^{-2}$ CND$\mathrm{CONH}_{2} / \mathrm{SPE}(\nabla)$ in saturated $\mathrm{O}_{2}$ solutions of (A) $0.1 \mathrm{M} \mathrm{H}_{2} \mathrm{SO}_{4}$ and (B) $0.1 \mathrm{M} \mathrm{KOH}$.

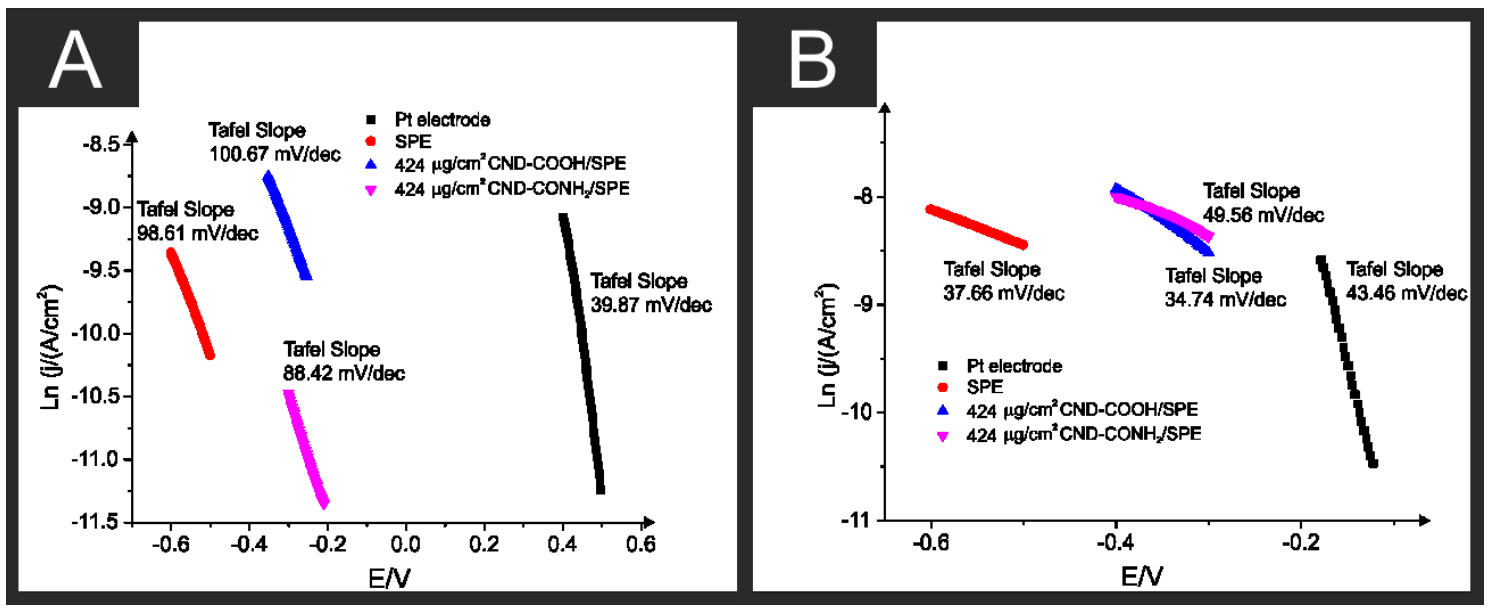


Figure S8. (A) Relative current vs. time measure using chronoamperometry applying $-0.4 \mathrm{~V}$ in $0.1 \mathrm{M} \mathrm{KOH}$ sat $\mathrm{O}_{2}$ using CND-COOH/SPE (black) and CND-CONH $2 / \mathrm{SPE}$ (red). (B) Same experiments adding methanol at 700 (1.5 M methanol cell concentration) and 1200 (3.0 M methanol cell concentration) seconds.

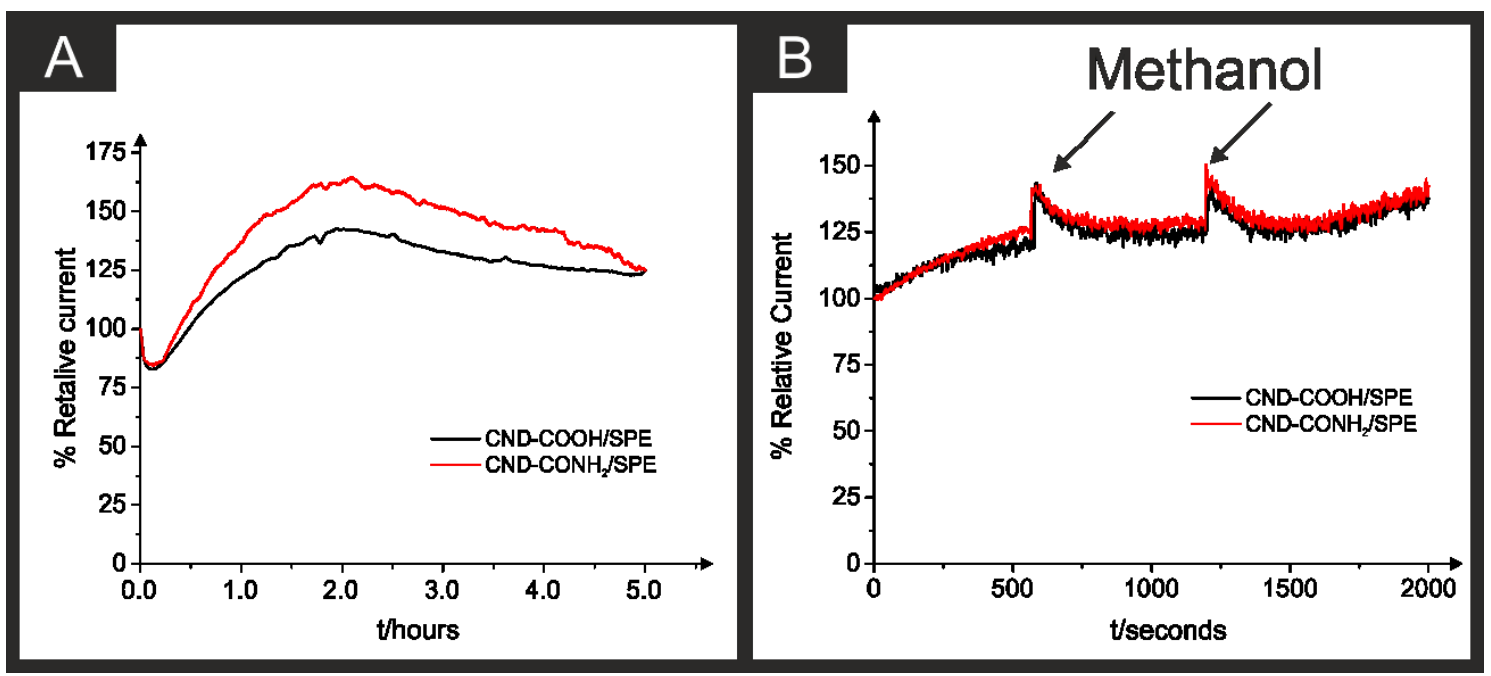




\section{References}

1. G. Wu, K. L. More, C. M. Johnston and P. Zelenay, Science, 2011, 332, 443-447.

2. $\quad$ B. C. H. Steele and A. Heinzel, Nature, 2001, 414, 345-352.

3. Y. Zheng, Y. Jiao, J. Chen, J. Liu, J. Liang, A. Du, W. Zhang, Z. Zhu, S. C. Smith, M. Jaroniec, G. Q. Lu and S. Z. Qiao, Journal of the American Chemical Society, 2011, 133, 2011620119.

4. J. H. Zagal and M. T. M. Koper, Angewandte Chemie International Edition, 2016, 55, 14510-14521.

5. S. J. Rowley-Neale, J. M. Fearn, D. A. C. Brownson, G. C. Smith, X. Ji and C. E. Banks, Nanoscale, 2016, 8, 14767-14777.

6. M. Gara and R. G. Compton, New J. Chem., 2011, 35, 2647-2652.

7. S. J. Rowley-Neale, D. A. C. Brownson, J. M. Fearn, G. C. Smith, X. Ji and C. E. Banks, Nanoscale, 2016, 8, 14767-14777.

8. L. Bu, S. Guo, X. Zhang, X. Shen, D. Su, G. Lu, X. Zhu, J. Yao, J. Guo and X. Huang, Nature Communications, 2016, 7, 11850.

9. N. S. Porter, H. Wu, Z. Quan and J. Fang, Accounts of Chemical Research, 2013, 46, 18671877.

10. L. Lin, Q. Zhu and A.-W. Xu, Journal of the American Chemical Society, 2014, 136, $11027-$ 11033.

11. H. Liu, W. Long, W. Song, J. Liu and F. Wang, Chemistry - A European Journal, 2017, 23, 2599-2609.

12. F. Neațu, M. M. Trandafir, M. Marcu, L. Preda, J. M. Calderon-Moreno, Ș. Neațu, S. Somacescu and M. Florea, Catalysis Communications, 2017, 93, 37-42.

13. Y. Dong, Y. Deng, J. Zeng, H. Song and S. Liao, Journal of Materials Chemistry A, 2017, 5, 5829-5837.

14. H. Yang, J. Liu, J. Wang, C. K. Poh, W. Zhou, J. Lin and Z. Shen, Electrochimica Acta, 2016, 216, 246-252.

15. Y. N. Regmi, G. R. Waetzig, K. D. Duffee, S. M. Schmuecker, J. M. Thode and B. M. Leonard, Journal of Materials Chemistry A, 2015, 3, 10085-10091.

16. A. F. Khan, M. P. Down, G. C. Smith, C. W. Foster and C. E. Banks, Journal of Materials Chemistry A, 2017, 5, 4103-4113.

17. A. F. Khan, E. P. Randviir, D. A. C. Brownson, X. Ji, G. C. Smith and C. E. Banks, Electroanalysis, 2017, 29, 622-634.

18. J. Liang, Y. Jiao, M. Jaroniec and S. Z. Qiao, Angewandte Chemie International Edition, 2012, 51, 11496-11500.

19. M. Klingele, C. Van Pham, A. Fischer and S. Thiele, Fuel Cells, 2016, 16, 522-529.

20. X. Zhang, D. Yu, Y. Zhang, W. Guo, X. Ma and X. He, RSC Advances, 2016, 6, 104183104192.

21. J. Zhang and L. Dai, ACS Catalysis, 2015, 5, 7244-7253.

22. J. Duan, S. Chen, M. Jaroniec and S. Z. Qiao, ACS Catalysis, 2015, 5, 5207-5234.

23. Y. Wang, M. Jiao, W. Song and Z. Wu, Carbon, 2017, 114, 393-401.

24. F. Gao, G.-L. Zhao, S. Yang and J. J. Spivey, Journal of the American Chemical Society, 2013, 135, 3315-3318.

25. K. Gong, F. Du, Z. Xia, M. Durstock and L. Dai, Science, 2009, 323, 760-764.

26. S. Wang, L. Zhang, Z. Xia, A. Roy, D. W. Chang, J.-B. Baek and L. Dai, Angewandte Chemie International Edition, 2012, 51, 4209-4212.

27. Y. Li, Y. Zhao, H. Cheng, Y. Hu, G. Shi, L. Dai and L. Qu, Journal of the American Chemical Society, 2012, 134, 15-18.

28. Z. Luo, S. Lim, Z. Tian, J. Shang, L. Lai, B. MacDonald, C. Fu, Z. Shen, T. Yu and J. Lin, Journal of Materials Chemistry, 2011, 21, 8038-8044. 
29. H. Li, Z. Kang, Y. Liu and S.-T. Lee, Journal of Materials Chemistry, 2012, 22, 24230-24253.

30. P. Miao, K. Han, Y. Tang, B. Wang, T. Lin and W. Cheng, Nanoscale, 2015, 7, 1586-1595.

31. J. Cao, Y. Hu, L. Chen, J. Xu and Z. Chen, International Journal of Hydrogen Energy, 2017, 42, 2931-2942.

32. R. Liu, H. Zhang, S. Liu, X. Zhang, T. Wu, X. Ge, Y. Zang, H. Zhao and G. Wang, Physical Chemistry Chemical Physics, 2016, 18, 4095-4101.

33. H. Zhang, Y. Wang, D. Wang, Y. Li, X. Liu, P. Liu, H. Yang, T. An, Z. Tang and H. Zhao, Small, 2014, 10, 3371-3378.

34. H. Zhang, J. Chen, Y. Li, P. Liu, Y. Wang, T. An and H. Zhao, Electrochimica Acta, 2015, 165, 7-13.

35. L. Zhou, P. Fu, Y. Wang, L. Sun and Y. Yuan, Journal of Materials Chemistry A, 2016, 4, 7222-7229.

36. G. H. G. Ahmed, R. B. Laíño, J. A. G. Calzón and M. E. D. García, Microchimica Acta, 2015, 182, 51-59.

37. H. Peng and J. Travas-Sejdic, Chemistry of Materials, 2009, 21, 5563-5565.

38. N. A. Choudry, D. K. Kampouris, R. O. Kadara and C. E. Banks, Electrochem. Commun., 2010, 12, 6-9.

39. L. R. Cumba, J. P. Smith, D. A. C. Brownson, J. Iniesta, J. P. Metters, D. R. D. Carmo. and C. E. Banks, Analyst, 2015, 140, 1543-1550.

40. C. W. Foster, J. Pillay, J. P. Metters and C. E. Banks, Sensors (Basel, Switzerland), 2014, 14, 21905-21922.

41. C. W. Foster, J. P. Metters and C. E. Banks, Electroanalysis, 2013, 25, 2275-2282.

42. J. P. Metters, M. Gomez-Mingot, J. Iniesta, R. O. Kadara and C. E. Banks, Sens. Actuators, $B, 2013,177,1043-1052$.

43. S. J. Rowley-Neale, D. A. C. Brownson, G. C. Smith, D. A. G. Sawtell, P. J. Kelly and C. E. Banks, Nanoscale, 2015, 7, 18152-18168.

44. S. J. Rowley-Neale, C. W. Foster, G. C. Smith, D. A. C. Brownson and C. E. Banks, Sustainable Energy Fuels, 2017, 1, 74-83.

45. M. Gara and R. G. Compton, New Journal of Chemistry, 2011, 35, 2647-2652.

46. U. A. Paulus, A. Wokaun, G. G. Scherer, T. J. Schmidt, V. Stamenkovic, V. Radmilovic, N. M. Markovic and P. N. Ross, The Journal of Physical Chemistry B, 2002, 106, 4181-4191.

47. G. Tuci, L. Luconi, A. Rossin, E. Berretti, H. Ba, M. Innocenti, D. Yakhvarov, S. Caporali, C. Pham-Huu and G. Giambastiani, ACS Applied Materials \& Interfaces, 2016, 8, 3009930106.

48. Y. Tang, B. L. Allen, D. R. Kauffman and A. Star, Journal of the American Chemical Society, 2009, 131, 13200-13201.

49. H. Tabassum, R. Zou, A. Mahmood, Z. Liang and S. Guo, Journal of Materials Chemistry A, 2016, 4, 16469-16475.

50. R. Maria Giron, J. Marco-Martinez, S. Bellani, A. Insuasty, H. Comas Rojas, G. Tullii, M. R. Antognazza, S. Filippone and N. Martin, Journal of Materials Chemistry A, 2016, 4, 14284-14290.

51. G. Panomsuwan, N. Saito and T. Ishizaki, Carbon, 2016, 98, 411-420.

52. A. Saha, S. K. Basiruddin, S. C. Ray, S. S. Roy and N. R. Jana, Nanoscale, 2010, 2, $2777-$ 2782.

53. Y. Dong, R. Wang, H. Li, J. Shao, Y. Chi, X. Lin and G. Chen, Carbon, 2012, 50, 2810-2815.

54. J. L. Hueso, J. P. Espinós, A. Caballero, J. Cotrino and A. R. González-Elipe, Carbon, 2007, 45, 89-96.

55. T. Sato, A. Narazaki, Y. Kawaguchi and H. Niino, Applied Physics A, 2004, 79, 1477-1479.

56. L. Bai, S. Qiao, Y. Fang, J. Tian, J. McLeod, Y. Song, H. Huang, Y. Liu and Z. Kang, Journal of Materials Chemistry C, 2016, 4, 8490-8495.

57. A. Dutta Chowdhury and R.-a. Doong, ACS Applied Materials \& Interfaces, 2016, 8, 21002-21010. 
58. R. Yang, X. Guo, L. Jia and Y. Zhang, Microchimica Acta, 2017, 184, 1143-1150.

59. E. P. Randviir and C. E. Banks, Electroanalysis, 2014, 26, 76-83.

60. D. A. C. Brownson and C. E. Banks, in The Handbook of Graphene Electrochemistry, Springer London, London, 2014, DOI: 10.1007/978-1-4471-6428-9_2, pp. 23-77.

61. T. Kaskiala, Minerals Engineering, 2002, 15, 853-857. 